THE YALE LAW JOURNAL FORUM

JUNE 18, 2018

\title{
Reconceptualizing Sexual Harassment, Again
}

\author{
Vicki Schultz
}

A B STRACT. Sexual harassment has always been more about sexism than it is about sex. Nearly twenty years ago, Vicki Schultz pioneered a new understanding of sexual harassment that recognized and theorized this empirical reality. The framework she developed in two articles published in the Yale Law Journal-Reconceptualizing Sexual Harassment and The Sanitized Workplace-still holds important lessons for today. The emergence of the \#MeToo movement has brought about a welcome, renewed focus on sexual harassment and motivated long-overdue terminations of accused harassers across industries. Yet pervasive narratives still narrowly emphasize sexualized forms of harassment and assault - at the expense of broader understandings of harassment and its causes. This Essay revisits and expands on Schultz's previous work in the contemporary context, drawing on the technology and film industries as case studies and showing that sex segregation and unchecked, subjective authority are central institutional causes of sex-based harassment. To end harassment will thus require more than firing individual harassers. It will require structural reform to eliminate arbitrary authority and sex segregation at work. Bold solutions are needed if we are to ensure sexual harassment isn't still prevalent twenty years from now. 


\section{ESSAY CONTENTS}

INTRODUCTION

I. THEORY

A. The Broad Range of Sex-Based Harassment

1. Hollywood's Harvey Weinstein 34

2. Silicon Valley 38

B. Legal and Social Effects $\quad 42$

C. Theoretical Implications $\quad 45$

II. FOUNDATIONS

A. Sex Segregation $\quad 49$

B. Unconstrained, Subjective Authority $\quad 50$

C. Contemporary Examples

1. Hollywood 53

2. Silicon Valley $\quad 56$

III. CHANGE

CONCLUSION 


\section{INTRODUCTION}

Twenty years ago, I published an article in the Yale Law Journal entitled Reconceptualizing Sexual Harassment. ${ }^{1}$ Five years later, I published a follow-up article in the same journal. ${ }^{2}$ These two pieces anchored a body of writing ${ }^{3}$ that proposed a new theory of sexual harassment. This theory sees harassment as an expression of workplace sexism, not sexuality or sexual desire. Harassment is a way for dominant men to label women (and perceived "lesser" men) as inferior and shore up an idealized masculine work status and identity. ${ }^{4}$

Recent events reveal that body of work as still depressingly relevant. Still relevant because sexual harassment remains far too widespread, despite forty years of activism and legal reform. And still relevant because the need for an adequate theoretical framework to guide action remains as pressing as ever, twenty years later.

Now is the time to reinvigorate theory. With the rise of the \#MeToo movement, we are witnessing an extraordinary cultural moment of resistance against sexual harassment-one that could galvanize real change. Most reports have focused on workplace or career-related harassment, ${ }^{5}$ a focus that is unsurprising given the centrality of work and workplace inequality to women's lives. ${ }^{6}$ For that reason, this Essay focuses on harassment at work, although

1. Vicki Schultz, Reconceptualizing Sexual Harassment, 107 YALE L.J. 1683 (1998).

2. Vicki Schultz, The Sanitized Workplace, 112 YALE L.J. 2061 (2003).

3. See, e.g., Vicki Schultz \& Eileen Goldsmith, Sexual Harassment: Legal Perspectives, in INTERNATIONAL ENCYClopedia of THE SOCIAL AND BeHAVIORAL SCIENCES 13982-87 (Paul B. Bates \& Neil J. Smelser eds., 2001); Vicki Schultz, Understanding Sexual Harassment Law in Action: What Has Gone Wrong and What We Can Do About It, 29 T. JEFFERSON L. Rev. 1 (2006); Vicki Schultz, Sex Is the Least of It: Let's Refocus Harassment Law on Work, Not Sex, NATion, MAY 25, 1998, at 11.

4. For an explanation of the theory, see Parts I and II infra. For examples of work citing, confirming, or following the theory, see notes 13-18 infra and accompanying text.

5. See, e.g., Jodi Kantor, \#MeToo Called for an Overhaul. Are Workplaces Really Changing?, N.Y. TIMES (Mar. 23, 2018), https://www.nytimes.com/2018/o3/23/us/sexual-harassmentworkplace-response.html [https://perma.cc/Z72K-KXZE]; Nicole Smartt, Sexual Harassment in the Workplace in a \#MeToo World, ForBES (Dec. 20, 2017, 9:00 AM), https://www .forbes.com/sites/forbeshumanresourcescouncil/2017/12/20/sexual-harassment-in-theworkplace-in-a-metoo-world [https://perma.cc/4TTW-SCDW]; Rebecca Traister, This Moment Isn't (Just) About Sex. It's Really About Work., Cut (Dec. 10, 2017, 9:00 PM), https://www.thecut.com/2017/12/rebecca-traister-this-moment-isnt-just-about-sex.html [https://perma.cc/7XFL-BN5 5 ].

6. See Discrimination in America: Experiences and Views of American Women, NPR ET AL. 2 (2017), https://cdn1.sph.harvard.edu/wp-content/uploads/sites/94/2017/12/NPR-RWJF- 
much of its analysis would apply also to harassment on college and school campuses and in other institutional settings.

There are reasons to be optimistic about the prospects for change. The audacity and sheer number of those who have come forward to tell their stories, the expressions of solidarity between women from different walks of life (Hollywood actors and migrant farm workers, for example), ${ }^{7}$ the serious and sustained attention to harassment by the media, the public's willingness to believe and support so many victims, and the fact that numerous organizations have responded to harassment allegations with serious measures are all hopeful signs. The renewed feminist commitment to activism and reform is also critically important. Legal and social advances to eliminate harassment and discrimination can only be made when feminists of all backgrounds and types come together to demand equality. ${ }^{8}$

Yet, there is also reason for concern - and much more hard work to do-if the current moment is to produce the lasting change that working women and men deserve. This period has produced many enlightening stories, and plenty of activism, but not enough intellectual analysis. The press showcases journalists, survivors, and political pundits discussing harassment, but has featured few scholars in major media outlets. Without serious reflection and analysis, we risk falling into the same traps that have hindered progress repeatedly in the past.

Take, for instance, the issue of remedies. Some commentators say that what is new this time around is that organizations are firing harassers, including formerly untouchable "star" performers. In fact, many of the mighty have fallen. ${ }^{9}$ It can, and often does, feel good to see powerful men who have treated

HSPH-Discrimination-Women-Final-Report.pdf [https://perma.cc/25FW-989E] (noting that "workplace discrimination remains the most frequently reported issue for women across racial and ethnic genders").

7. See, e.g., Time Staff, 7oo, ooo Farmworkers Say They Stand With Hollywood Actors Against Sexual Assault, TIME (Nov. 10, 2017), http://time.com/5018813/farmworkers-solidarityhollywood-sexual-assault/ [https://perma.cc/5U7Q-7Q2E] (reprinting the powerful "Dear Sisters" letter penned by female Latina farmworkers expressing solidarity with Hollywood actors experiencing sexual assault); see also Cara Buckley, Powerful Hollywood Women Unveil Anti-Harassment Action Plan, N.Y. Times (Jan. 1, 2018), https://www.nytimes.com/2018 /01/o1/movies/times-up-hollywood-women-sexual-harassment.html [https://perma.cc /E42G-DMTV] (detailing the Time's Up initiative proposed by 300 Hollywood women "to fight systemic sexual harassment in Hollywood and in blue-collar workplaces nationwide").

8. See generally Vicki Schultz, Taking Sex Discrimination Seriously, 91 DeNV. U. L. ReV. 995 (2015) (showing how Second Wave feminism made legal strides when women united to challenge sex difference and demand equality).

9. See Sarah Almukhtar, Michael Gold \& Larry Buchanan, After Weinstein: 71 Men Accused of Sexual Misconduct and Their Fall from Power, N.Y. TIMES (Feb. 8, 2018), 
others so badly get their come-uppance; it is important for organizations to hold them accountable. But there are inherent limits to such an approach. Firing harassers does nothing to repair the severe professional and personal setbacks suffered by victims, many of whom have left careers they loved and continue to suffer trauma. Nor does firing those individual harassers ensure that similar conduct does not recur in the future. It may provide a short-term deterrent, but sooner or later, other harassers will take their place-unless the underlying conditions that foster harassment in the first place are addressed. If research teaches us anything, it is that harassment is a widespread institutional problem that cannot be solved by firing or punishing harassers one by one.

This Essay revisits my earlier work and breaks new theoretical ground to explain why bold new solutions are needed to eliminate sexual harassment in the current age. Part I briefly elaborates the theory of sexual harassment, describing the wide range of forms of harassment and explaining what is at stake for the harassers from a combined social psychological, sociological, and legal perspective. This Part then introduces examples involving Hollywood film producer Harvey Weinstein and the Silicon Valley technology industry to illustrate and further inform the theory. These examples reveal how explicitly sexual misconduct is typically only one manifestation of a broader pattern of sexism, harassment, and discrimination that is motivated less by sexual desire than by a drive to reinforce masculine workplace status and identity. Part III deepens the theory and shows how two prevalent structural features of workplaces encourage harassment: first, the sex segregation of men and women into different positions or roles, and second, the allocation and use of unchecked, subjective authority to determine people's career and life prospects. This Part returns to Hollywood and Silicon Valley to illustrate these problems, explaining how entrenched sex segregation and unaccountable authority have fostered harassment and discouraged victims from resisting it in both industries. Part IV discusses the implications of this theory and stresses the need for structural reforms - not just individual solutions - in order to end sexual harassment. The Essay ends with a renewed vision for law reform and activism and a call to refashion our workplaces and institutions to ensure greater equality and openness, freedom from arbitrary authority, and freedom from sexual harassment.

https://www.nytimes.com/interactive/2017/11/10/us/men-accused-sexual-misconductweinstein.html [https://perma.cc/L8LJ-GD63]. 


\section{THEORY}

To create lasting change requires an informed theory of sexual harassment: what is harassment? What is in it for the harassers? What causes harassment? To prevent it, what must change?

Two decades ago, I proposed a new theory of harassment that challenged the prevailing orthodoxy. The older view defined sexual harassment as unwanted sexual advances, typically by powerful men toward their female subordinates. I called this view the sexual desire-dominance paradigm. ${ }^{10}$ Harassment in that paradigm is a top-down, male-to-female, sexual phenomenon, driven by sexual desire. It has little to do with work or workplace conditions; it is about predatory sexuality. Men merely use their positions at work, in this theory, to satisfy their urge to dominate women sexually.

My theory challenged this narrow sexual focus. In my view, sexual harassment is a means of maintaining masculine work status and identity, not expressing sexuality or sexual desire. Harassment includes not only unwanted sexual advances but also a wide range of other sexist, demeaning behaviors aimed at women and others who threaten settled gender norms. Harassment is linked to broader forms of sex discrimination and inequality, ${ }^{11}$ because some men harass women and "lesser men" to preserve their dominant workplace position and related sense of manhood. Sexualized behavior is often a tool of harassment, in this theory, but sexuality is not inherently degrading or discriminatory. ${ }^{12}$ My writing elaborated this view in the context of employment, stressing the importance of traditionally male forms of work to mainstream masculine

10. See Schultz, supra note 1 , at 1686, 1692 (introducing the term); id. at 1686-88, 1692-96, $1698-99,1702-05$ (citing numerous examples of popular incidents, press coverage, academic research, feminist theory, and legal reasoning conforming to this paradigm). For example, the original EEOC guidelines on sexual harassment defined the underlying conduct as "unwelcome sexual advances, requests for sexual favors, or other verbal or physical conduct of a sexual nature." See EEOC Guidelines on Discrimination Because of Sex, 29 C.F.R. $\$ 1604.11$ (1997) (emphasis added). Numerous legal decisions limited harassment claims to such sexual conduct. See, e.g., Schultz, supra note 1, at 1716-20 \& nn. 166-168 (collecting cases). Some feminists supported this view, analogizing sexual harassment to rape and arguing that it was harmful precisely because it was sexual. See, e.g., Catharine A. MacKinnon, SeXual Harassment of Working Women: A CASE Study of Discrimination (1979); Susan Estrich, Sex at Work, 43 STAN. L. REV. 813, 820 (1991). The news media contributed to the problem, publicizing male-female harassment involving sexualized misconduct in salacious terms, while neglecting broader forms of sex-based harassment and discrimination. See Schultz, supra note 1, at 1692-96.

11. See infra Parts III.A., III.C.1., and III.C.2; see also Schultz, supra note 1, at 1755-74.

12. See Schultz, supra note 2 , at 2136-39. 
status and selfhood. But the theory also applies more broadly to other institutions that help shape and reinforce gender identity.

This newer theory has taken hold in many quarters. First and foremost, it has been affirmed in the law. The United States Supreme Court has acknowledged explicitly that workplace harassment does not have to be explicitly "sexual" in content or motivation to be actionable, ${ }^{13}$ and, conversely, that not all sexually tinged conduct amounts to harassment. ${ }^{14}$ Instead, the touchstone is whether the misconduct occurs because of sex. Thus, the law has come to recognize that same-sex harassment is also actionable. ${ }^{15}$ The Equal Employment Opportunity Commission (EEOC) has also clarified that harassment includes any conduct that demeans people at work because of their sex or gender, regardless of whether it is sexual in nature. ${ }^{16}$ Many lower courts have affirmed and elaborated on these ideas. ${ }^{17}$

13. Oncale v. Sundowner Offshore Servs., Inc., 523 U.S. 75, 8o (1998) (" $[\mathrm{H}]$ arassing conduct need not be motivated by sexual desire to support an inference of discrimination on the basis of sex.").

14. Id. ("We have never held that workplace harassment, even harassment between men and women, is automatically discrimination because of sex merely because the words used have sexual content or connotations.").

15. Id. at 79-80 (holding that Title VII prohibits same-sex harassment and all other forms of harassment that amount to "'discriminat[ion] . . . because of . . . sex' in the 'terms' or 'conditions' of employment"). The Editors of the Yale Law Journal circulated the page proofs of my first article to the Justices of the United States Supreme Court while the Oncale case was pending before the Court in 1998. The article criticized equating harassment with sexual conduct, Schultz, supra note 1, at 1704-05, 1713-29, insisted on a "sex-based" definition of harassment that includes both sexual and nonsexual conduct, $i d$. at 1796-180o, and argued that same-sex harassment should be covered under the law, $i d$. at 1774-89, 1801-o2. These are all propositions the Oncale Court formally endorsed.

16. The EEOC's revised definition of sexual harassment, posted in guidance on its website, provides: "It is unlawful to harass a person (or applicant or employee) because of that person's sex. Harassment can include 'sexual harassment' or unwelcome sexual advances, requests for sexual favors, or other verbal of physical conduct of a sexual nature. Harassment does not have to be of a sexual nature, however, and can include offensive remarks about a person's sex. For example, it is illegal to harass a woman by making offensive comments about women in general." Sexual Harassment, U.S. EQUAL EMP. OPPORTUNITY COMMISSION, https://www.eeoc .gov/laws/types/sexual_harassment.cfm [https://perma.cc/3QWV-4WHN] (emphasis added); see also Harassment, U. S. EQUAL EMP. OPPORTUNiTy COMMISSION, https://www .eeoc.gov/laws/types/harassment.cfm [https://perma.cc/6XJ5- $\left.\mathrm{AZ}_{3} \mathrm{R}\right]$ ("Harassment is unwelcome conduct that is based on race, color, religion, sex (including pregnancy), national origin, age (40 or older), disability or genetic information.").

17. Numerous courts of appeals have reiterated that actionable harassment need not be sexual in nature. See, e.g., Gregory v. Daly, 243 F.3d 687, 695 (2d Cir. 2001) (citing Schultz, supra note 1 , for this proposition). Some courts of appeals have also followed my suggestion that both sexual and nonsexual conduct should be considered together for purposes of assessing 
This newer view of harassment has informed a great deal of empirical research, led to exciting new theorizing, ${ }^{18}$ and inspired other progressive legal reforms. ${ }^{19}$

whether all alleged misconduct amounts to a hostile work environment. See e.g., O'Rourke v. City of Providence, 235 F.3d 713, 730 \& n.5 (1st Cir. 2001) (citing Schultz, supra note 1, for this proposition); Durham Life Ins. Co. v. Evans, 166 F.3d 139, 149 (3d Cir. 1999) (same). Other decisions have acknowledged explicitly that men's harassing other men for failing to conform to idealized norms of masculinity is sex-based harassment that violates Title VII, a point my work championed. See, e.g., Rene v. MGM Grand Hotel, Inc., 305 F.3d 1061, 1069 n.3 (9th Cir. 2002) (quoting Schultz, supra note 1 , at 1755 n.387, for the idea that some "male workers may view not only their jobs, but also the male-dominated composition and masculine identification of their work, as forms of property to which they are entitled"). Indeed, after two decades of judicial decisions acknowledging that the harassment of gay men and other gender-nonconforming men and women violates Title VII's prohibition on sex stereotyping and sex discrimination, some courts of appeals are beginning to hold that discrimination on the basis of sexual orientation is itself a form of sex stereotyping and sex discrimination prohibited under Title VII. See, e.g., Zarda v. Altitude Express, Inc., 883 F.3d 100 (2d Cir. 2018) (en banc); Hively v. Ivy Tech Cmty. Coll. of Ind., 853 F.3d 339 (7th Cir. 2017) (en banc).

18. For examples of social science research in this new direction, see George Akerlof \& Rachel Kranton, Economics and Identity, 3 Q. J. ECON. 715, 733 \& n.37 (200o) (citing Schultz, supra note 1 , and proposing a new economic approach that considers social identity to explain workplace harassment and labor market outcomes); Jennifer L. Berdahl, Harassment Based on Sex: Protecting Social Status in the Context of Gender Hierarchy, 32 Acad. MgmT. Rev. 641 (2007) (following Schultz, supra note 1 , in defining sex-based harassment broadly to include nonsexual forms of harassment, rejecting sexual desire or a desire for sexual dominance as adequate explanations for harassment, and proposing a similar theory based on perceived threat to social status and identity); Emily A. Leskinen, Lilia M. Cortina \& Dana B. Kabat, Gender Harassment: Broadening Our Understanding of Sex-Based Harassment at Work, 35 J. L. \& Hum. BeHAV. 25, 36 (citing Schultz, supra note 1, and arguing that their "empirical results support the theory that harassment is about gender, not sexuality"); and Sandy Welsh, Gender and Sexual Harassment, 25 ANN. Rev. Soc. 169, 175 (1999) (citing Schultz, supra note 1, to acknowledge broader, nonsexual forms of harassment and calling on social science researchers to take account of harassment that does not fit the "top-down, male-female sexual come-on image of harassment" paradigm).

19. Title IX's reach now extends beyond conduct of a sexual nature, for example, to cover all campus sex- and gender-based harassment, including harassment of gender nonconforming people, as I called for under Title VII. See, e.g., Office for Civil Rights, Dear Colleague Letter: Harassment and Bullying, U.S. DEP'T OF EDUC. (Oct. 26, 2010) https://www2.ed.gov/about/offices/list/ocr/letters/colleague-201010.pdf [https://perma.cc $\left./ \mathrm{RM}_{7} \mathrm{~F}-83 \mathrm{AK}\right]$ (clarifying that peer harassment based on sex, as well as race, color, national origin, or disability, violates Title IX when it is sufficiently severe, pervasive, or persistent to interfere with or limit a student's ability to participate in or benefit from the services, activities, or opportunities offered by a school, and providing examples of both sexual and gender-based harassment); Office for Civil Rights, Sex-Based Harassment, U.S. DEP'T OF EDUC. (Nov. 17, 2017) https://www2.ed.gov/about/offices/list/ocr/frontpage/pro-students/issues /sex-issueo1.html [https://perma.cc/Z4KE-TUBW] (stating that "Title IX requires schools to prevent and remedy two forms of sex-based harassment: sexual harassment (including sexual violence) and gender-based harassment," and defining the latter to include "unwel- 
It has also been taken up by many younger feminists and queer theorists, ${ }^{20}$ and extended to institutional realms beyond the workplace. ${ }^{21}$

But the old orthodoxy still has cultural currency, and I worry that it will gain ascendancy again in the absence of vigorous public debate and education, impeding our ability to move forward with systemic change. There are signs that many people who identify with the \#MeToo movement are guided, consciously or unconsciously, by the older understanding of sexual harassment. The movement was rekindled soon after the story broke about Harvey Weinstein, when actress Alyssa Milano asked her Twitter followers, "If you've been sexually harassed or assaulted write 'me too' as a response to this tweet." 22 Alt-

come conduct based on a student's sex [and] harassing conduct based on a student's failure to conform to sex stereotypes"); Departments of Justice and Education Reach Agreement with Tehachapi, Calif., Public Schools to Resolve Harassment Allegations, U.S. DeP'T OF EdUC. (July 1, 2011) https://www.ed.gov/news/press-releases/departments-justice-and-educationreach-agreement-tehachapi-calif-public-schools-resolve-harassment-allegations [https:// perma.cc/PN7J-KX7R] (reporting resolution agreement with California school system where a middle school student committed suicide after experiencing an escalating campaign of verbal, physical, and sexual harassment due to failure to conform to gender stereotypes). For an overview of the relevant law that explains how Title IX relies on Title VII principles, the same principles that I urged in my earlier work, see Adele P. Kimmel, Title IX: An Imperfect but Vital Tool to Stop Bullying of LGBT Students, 125 YALE L.J. 2006, 2016-23 (2016).

20. See, e.g., Brian Soucek, Queering Sexual Harassment Law, 128 YALE L.J.F. 67, (2018); Melissa Gira Grant, The Unsexy Truth About Harassment, N.Y. REV. BOOKS DAILY (Dec. 8, 2017, 6:06 PM), http://www.nybooks.com/daily/2017/12/o8/the-unsexy-truth-about-harassment [https://perma.cc/9R2Z-WKST]; Anna North, What I've Learned Covering Sexual Misconduct This Year, Vox (Dec. 27, 2017, 1:10 PM), https://www.vox.com/identities/2017/12 /27/16803610/sexual-misconduct-harassment-reckoning-metoo [https://perma.cc/9S2L2573]; Traister, supra note 5; Jane Ward, Bad Girls: On Being the Accused, BULLY BlogGers (Dec. 21, 2017), https://bullybloggers.wordpress.com/2017/12/21/bad-girls-on-being-theaccused/ [https://perma.cc/EZ44-CVSU].

21. Scholars have used the ideas put forward in my earlier work to call for efforts to address nonsexual harassment and sex segregation in a variety of contexts other than employment. For a few examples, see Deborah Brake, The Struggle for Sex Equality in Sport and the Theory Behind Title IX, 34 U. MicH. J.L. REFORM 13, 29-30, 36-38 \& 70-74 (2000) (sports); B. Glenn George, Forfeit: Opportunity, Choice, and Discrimination Theory Under Title IX, 22 YALE J.L. \& FEMINISM 1, 26, 31-32 (2010) (same); Naomi Schoenbaum, Gender and the Sharing Economy, 43 FordHAM URB. L.J. 1023, 1055-56 (2016) (sharing economy); and Deborah M. Thompson, "The Woman in the Street:" Reclaiming the Public Space from Sexual Harassment, 6 YALE J.L. \& FEMINISM 313, 323-24, 335 (1994) (street harassment). Reformers have also drawn on my work elaborating how sex segregation fosters sexual harassment to demand the elimination of sex segregation in fraternities and other social spaces on college campuses. See Research, ENGENDER https://www.engender.space/research [https://perma.cc/AER6-UF7T] (collecting sources).

22. @Alyssa_Milano, TwitTer (Oct. 15, 2017, 1:21 PM) https://twitter.com/alyssa_milano /status/919659438700670976 ?lang=en [https://perma.cc/S3KV-NGX6]. It is important to 
hough I have found no systematic empirical research on this point, ${ }^{23}$ it seems clear that most of the ensuing \#MeToo posts focused on specifically sexual forms of harassment and abuse, including sexual assault, and not on broader patterns of sexism and discrimination. Most of the tweets that were most frequently retweeted in the first month, for example, referenced sexual misconduct. ${ }^{24}$ Data visualizations of tweets in that period feature words like "sexual," "sexually," "rape," "survivor," "violence," "assault," "predator," "abuse," "exploitation" - all words associated with explicitly sexual forms of misconductand names like "weinstein," "harvey," "billoreilly," "trump," "louisck," "roymoorechildmolester" - all people accused of this type of conduct. ${ }^{25}$ A survey commissioned in February 2018, The Facts Behind the \#MeToo Movement, also focused almost exclusively on sexualized forms of harassment, verbal and physical. ${ }^{26}$

Furthermore, from the beginning, media stories reporting on the movement have, explicitly or implicitly, limited their definition of sexual harassment to unwanted sexual overtures or other specifically sexual forms of abuse - despite the fact that the legal definition of harassment covers broader forms of sex-based misconduct and has done so for twenty years. Notably, the New York

note that Milano was picking up on work that Tarana Burke, a Black feminist activist who is credited with launching the "Me Too" movement in 2007, had started. See Sandra E. Garcia, The Woman Who Created \#MeToo Long Before Hashtags, N.Y. TimES (Oct. 20, 2017), https://www.nytimes.com/2017/10/20/us/me-too-movement-tarana-burke.html [https:// perma.cc/Z62D-QAMJ]; cf. Angela Onwuachi-Willig, What About \#UsToo?: The Invisibility of Race in the \#MeToo Movement, 128 YALE L.J.F. 105, 105-08 (2018) (describing Burke's role in the \#MeToo movement).

23. Some data analyses have been reported, but they do not address the extent to which the tweets refer to specifically sexual forms of harassment or abuse, as opposed to broader nonsexual forms. See, e.g., \#MeToo-The Viral Event of 2017, EzYINSIGHTS (Nov. 29, 2017), http://ezyinsights.com/metoo-viral-event-2017-1 [http://perma.cc/87S4-YZZF]; Hugo Browne-Anderson, How the \#MeToo Movement Spread on Twitter, DATACAMP (Nov. 14, 2017), http://www.datacamp.com/community/blog/metoo-twitter-analysis [http://perma .cc/8GS 3 -ZNWG]; Elise Zaidi, From Viral Hashtag to Social Movement, GSPM Researchers Track \#MeToo, GW HATCHET (Jan. 29, 2018), http://www.gwhatchet.com/2018/o1/29 /from-viral-hashtag-to-social-movement-gspm-researchers-track-metoo [http://perma.cc /9QW3-GWCN].

24. See Browne-Anderson, supra note 23 (reporting that some of the most retweeted tweets at the time of analysis included tweets by Monica Lewinsky, Marlee Matlin, Breanna Stewart, and Alice Glass, all of whom have reported specifically sexual relationships and misconduct).

25. See id. (data visualization chart); EzYINSIGHTS, supra note 23 (data visualization chart).

26. The Facts Behind the \#MeToo Movement: A National Study on Sexual Harassment and Sexual Assault, StoP StreEt HARASSMENT 1 (Feb. 2018), http://www.stopstreetharassment.org /wp-content/uploads/2018/o1/Survey-Questions-2018-National-Study-on-SexualHarassment-and-Assault.pdf [http://perma.cc/3 $\left.\mathrm{UZF}-\mathrm{K}_{7} 6 \mathrm{Y}\right]$. 
Times, whose reporters broke the Weinstein story, has publicly defined "sexual harassment in the workplace" in explicitly sexual terms: "The Times uses the terms 'sexual harassment' and 'sexual misconduct' to refer to a range of behaviors that are sexual in nature and nonconsensual. The term 'sexual assault' usually signifies a felony sexual offense, like rape." ${ }^{27}$ This definition likens workplace sexual harassment to sexual assault and rape - not to other forms of sexbased harassment and discrimination, as the legal definition does. ${ }^{28}$ Most press reporting and social coverage about \#MeToo has tended to adopt a similarly limited sexual focus, ${ }^{29}$ despite two decades of efforts by feminists in law, social science, and activist circles to create a broader, more accurate picture of the harassment and discrimination most working women and LGBTQ people face.

27. Natalie Proulx, Christopher Pepper \& Katherine Shulten, The Reckoning: Teaching About the \#MeToo Movement and Sexual Harassment with Resources, N.Y. TIMES (Jan. 25, 2018), https://www.nytimes.com/2018/o1/25/learning/lesson-plans/the-reckoning-teachingabout-the-metoo-moment-and-sexual-harassment-with-resources-from-the-new-yorktimes.html [https://perma.cc/KC6R-DPDP]. The article also states: "Sexual harassment in the workplace is an umbrella term that encompasses a range of unwanted behaviors. This includes nonphysical harassment, including suggestive remarks and gestures, or requests for sexual favors. Physical harassment includes touches, hugs, kisses and coerced sex acts." Id. In addition to adopting this explicitly sexual definition, the article refers readers to examples in a United Nations document on sexual harassment. See id. (linking to What is Sexual Harassment?, UNITED NATIONS, http://www.un.org/womenwatch/osagi/pdf/whatissh.pdf [https://perma.cc/UCM6-KHV9], a document that also defines harassment exclusively in sexual terms and discusses only sexualized harassment); see also Valeriya Safronoya, When You Experience Sexual Harassment at Work, N.Y. TIMES (Nov. 10, 2017), https://www .nytimes.com/2017/11/10/style/sexual-harassment-work-advice-lawyers.html [https:// perma.cc/5745-4NSM] (adopting the same narrow sexual definition in an earlier piece).

28. The New York Times was apparently aware that the legal definition of sexual harassment is not limited to conduct of a sexual nature. The Times article, noted above, which defines the newspaper's use of harassment in sexual terms, refers readers seeking more information to the EEOC's legal definition of sexual harassment and provides a link. Proulx et al., supra note 27 (linking to https://www.eeoc.gov/laws/types/sexual_harassment.cfm [https:// perma.cc/RS7E-V $7 F X]$ ). The linked EEOC web page defining sexual harassment adopts the broader definition approved by the Supreme Court in Oncale v. Sundowner Offshore Servs., Inc., 523 U.S. 75 (1998), see supra notes $14-16$, providing that "[i]t is a unlawful to harass a person ... because of that person's sex" and noting expressly that "[h] arassment does not have to be of a sexual nature." Laws, Regulations and Guidance: Sexual Harassment, EQUAL EMP. OPPORTUNiTY COMMISSION, https://www.eeoc.gov/laws/types/sexual_harassment .cfm [https://perma.cc/DJM7-69PW]; see also supra note 27 (quoting the EEOC definition on that page in full).

29. Examples here are too numerous to cite. Time Magazine's "Person of the Year" issue, The Silence Breakers, implicitly adopted such a perspective. See Stephanie Zacharek et al., The Silence Breakers, TIME (Dec. 18 2017), http://time.com/time-person-of-the-year-2017-silencebreakers/ [https://perma.cc/W9DS-YF47]. 
This purely sexual lens represents a step backward, not forward. The law has come to recognize that harassment consists of many forms of sexist, hostile and discriminatory conduct, based on sex or gender stereotypes, that go beyond sexual overtures. ${ }^{30}$ Recognizing these broader forms of harassment does not mean that sexual misconduct is not important. It is, of course, crucial to expose and address unwanted sexual advances and assaults in the workplace (and other realms). Sexual abuse has remained hidden in the dark shadows of organizational and social life for too long. We, as a society, must be more willing to acknowledge sexual abuse and talk about it honestly and directly, just as we do other forms of abuse, without a sense of denial, shame, or discomfort. Organizations can and should hold harassers accountable for sexual misconduct just as they do other forms of mistreatment and discrimination, without excusing it as a personal predilection or a perk of the powerful.

But targeting only sexual misconduct without addressing related patterns of sexism and deeper institutional dynamics has serious shortcomingsshortcomings that risk undermining the broader quest for gender equality. This point applies beyond the context of workplace harassment. The \#MeToo movement has exposed sexual assaults and abuse in arenas other than workplaces, such as schools, churches, fraternities, families, and prisons. No matter where it appears, sexuality does not exist in a vacuum; sexual behavior is always a product not simply of innate individual desires, but also of institutional forces that evoke, shape, and give it meaning. Thus, regardless of whether sexual misconduct occurs at work or elsewhere, it has inevitably been facilitated and formed by these larger contextual forces. We must address these forces head-on if we are to end the full spectrum of harassment and discrimination of both the sexual and nonsexual kinds.

\section{A. The Broad Range of Sex-Based Harassment}

Focusing narrowly on male-to-female, unwanted sexual advances blinds us to the pervasive and pernicious nonsexual forms of sexism and harassment that women and others experience. Harassment does not always consist of unwanted sexual advances; a wide range of nonsexual actions is used to denigrate women and label them as "different" because of their sex.

In fact, contrary to popular perceptions, nonsexual forms of sex-based harassment and hostility are far more prevalent than unwanted sexual overtures. Harassment takes a wide variety of nonsexual forms, including hostile behav-

30. For Title VII and workplace, see sources cited supra notes 14-18. For Title IX and campuses, see sources cited supra note 19 . 
ior, physical assault, patronizing treatment, personal ridicule, social ostracism, exclusion or marginalization, denial of information, and work sabotage directed at people because of their sex or gender. This harassment is not only directed at heterosexual women: men who do not conform to prescribed images of masculinity and others who threaten established gender norms are subjected to similar harassment. Research suggests that most harassment aims to shore up masculine workplace superiority, not to secure sexual gratification. ${ }^{31}$ Most of the time, even unwanted sexual overtures are part of a broader pattern of sex-based harassment and hostility. ${ }^{32}$

Years ago, I elaborated on these points, drawing examples from a wide range of industries, occupations, and jobs. ${ }^{33}$ By all accounts, little has changed, especially in the traditionally male-dominated industries, organizations, and jobs where harassment is most prevalent. Consider the following examples from the Hollywood film industry and the Silicon Valley technology industry. These industries profoundly impact and shape American society and attract aspirants from all different backgrounds. Both remain highly unequal along sex, gender, and other lines.

\section{Hollywood's Harvey Weinstein}

Hollywood movie mogul Harvey Weinstein is widely portrayed as the quintessential sexual predator. ${ }^{34}$ Yet, a closer look reveals that even his preda-

31. See, e.g., Berdahl, supra note 18 , at 643 (stating that "the most common form of sexual harassment is gender harassment, which involves ... sexist comments, jokes, and materials that alienate and demean victims based on sex rather than solicit sexual relations with them"); Jennifer L. Berdahl, The Sexual Harassment of Uppity Women, 92 J. ApPLIED PsYchol. 425, 429 (showing that "women with relatively masculine personalities experience[d] the most sexual harassment," not those with feminine attributes); Heather McLaughlin, Christopher Uggen \& Amy Blackstone, Sexual Harassment, Workplace Authority, and the Paradox of Power, 77 AM. SOC. REv. 625, 627 (collecting studies).

32. See, e.g., Jennifer L. Berdahl \& Jana L Raver, Sexual Harassment, in 3 AMERICAN PsychologiCAL AsSociation HaNdBoOK of INDUSTRIAL AND ORganizational PSYCHOLOGY 646 (2011) (collecting studies showing that unwanted sexual attention and sexual coercion co-occurs with gender-based harassment, as well with other types of harassment); Emily A. Leskinen et al., supra note 18 , at 25, 31,34; Sandy Lim \& Lilia M. Cortina, Interpersonal Mistreatment in the Workplace: The Interface and Impact of General Incivility and Sexual Harassment, 90 J. APPLIED PSYCHOL. 483, 487, 49o; see also Louise F. Fitzgerald, Michele J. Gelfand \& Fritz Drasgow, Measuring Sexual Harassment: Theoretical and Psychometric Advances, 17 BASIC \& APPLIED SOC. PSYCHOL. 425, 438 (1995).

33. Schultz, supra note 1, at 1755-62; Schultz, supra note 2, at 2074-87.

34. Jodi Kantor and Megan Twohey broke the Weinstein story on October 5, 2017. See Jodi Kantor \& Megan Twohey, Harvey Weinstein Paid off Sexual Harassment Accusers for Decades, N.Y. 
tions were part of a broader campaign of nonsexual abuse, hostility, and sex discrimination. Numerous reports have described Weinstein's sexual aggressions, revealing how he preyed on young actresses and models seeking to advance in the film industry by allegedly pressuring them for sex, exposing himself, groping them and forcing himself on some of them, enticing them with promises of stardom, and threatening to ruin them if they didn't go along. ${ }^{35}$

Far fewer reports have covered the nonsexual, but still utterly sexist, forms of abuse Weinstein heaped upon less influential women who worked for him. Zelda Perkins worked as Weinstein's assistant for nineteen years. She stated that Weinstein repeatedly harassed her in both sexual and nonsexual ways. ${ }^{36}$ Not only did Weinstein work in the nude, ask to be massaged and to give her massages, and bathe in front of Perkins, he also yelled and cursed at her continually, and wore her down emotionally, especially after she had the temerity to stand up to him. ${ }^{37}$ Perkins says Weinstein never threatened her physically, but "she was constantly threatened "emotionally and psychologically." 38 Perkins resigned and tried to sue Weinstein for harassment, but was pressured in-

TIMES (Oct. 5, 2017), https://www.nytimes.com/2017/10/05/us/harvey-weinsteinharassment-allegations.html [https://perma.cc/AY97-XAH4]. Since then, news media have covered Weinstein's sexual aggressions extensively, with stories too voluminous to cite. See, e.g., Ronan Farrow, From Aggressive Overtures to Sexual Assault: Harvey Weinstein's Accusers Tell Their Stories, NEw YoRKER (Oct. 23, 2017), https://www.newyorker.com/news/newsdesk/from-aggressive-overtures-to-sexual-assault-harvey-weinsteins-accusers-tell-their-

stories [https://perma.cc/Q4JN-V8GQ]. Weinstein has now been arrested and charged with rape and criminal sexual assault in New York. James C. McKinley, Jr., Harvey Weinstein Indicted on Rape and Criminal Sexual Act Charges, N.Y. TIMES (May 30, 2018) https://www.nytimes.com/2018/o5/30/nyregion/weinstein-indicted-rape.html [https:// perma.cc/G7YE-DGLT]; Benjamin Mueller \& Alan Feuer, "Arrested on Rape Charges, Weinstein Posts \$1 Million Bail, N.Y. TIMES (May 25, 2018) https://www.nytimes.com /2018/05/25/nyregion/harvey-weinstein-arrested.html [https://perma.cc/3DSN-MVKA].

35. See Farrow, supra note 34; Kantor \& Twohey, supra note 34; Sara M. Moniuszko \& Cara Kelly, Harvey Weinstein Scandal: A Complete List of the 85 Accusers, USA TODAY (Mar. 22, 2018), https://www.usatoday.com/story/life/people/2017/10/27/weinstein-scandalcomplete-list-accusers/804663001/ [https://perma.cc/96PR-6TSV].

36. See Matthew Garrahan, Harvey Weinstein: How Lawyers Kept a Lid on Sexual Harassment Claims, Fin. TImes (Oct. 23, 2017), https://www.ft.com/content/1dc8a8ae-b7eo-11e7-8c125661783e5589 [https://perma.cc/4VZT-HVM4]; Emily Longeretta, Harvey Weinstein's Ex Assistant Opens Up About Working for 'Repulsive Monster', Us WeEKLY (Dec. 20, 2017), https://www.usmagazine.com/celebrity-news/news/harvey-weinsteins-ex-assistant-talksworking-for-repulsive-monster [https://perma.cc/4TX2-GLWW].

37. Perkins recounts an early incident: "I remember taking a call in the room when another call came through on another phone. He swore at me to 'pick up the $f^{\star \star \star}$ ing phone'. I said: 'I'm already on the $\mathrm{f}^{\star \star \star}$ ing phone!' It sealed my fate as someone who could stand up to him." Garrahan, supra note 36 .

38. Longeretta, supra note 36 . 
to a secret settlement in a process she says left her broken. ${ }^{39}$ Afterward, Perkins could not find work anywhere in the industry and was so devastated she moved all the way to Central America to heal. ${ }^{40}$

Perkins's experience was not atypical. According to a complaint filed by the New York State Attorney General after an extensive four-month investigation, ${ }^{41}$ Weinstein committed pervasive sexual and nonsexual harassment and discrimination against employees, creating a hostile work environment "permeated with gender-based hostility and inequality." ${ }^{2}$ In addition to unwanted sexual advances, Weinstein "regularly berated women using gender-based obscenities and stereotypes," ${ }^{43}$ yelled that they should leave and make babies since that was all they were good for, demanded to know if they had their periods, and accused them of wanting "special treatment" because of their sex. ${ }^{44}$ Weinstein did not target only women for such gendered opprobrium. He also used homophobic slurs and gender-based insults to degrade and scold men and to attack their masculinity. ${ }^{45}$

Certain other forms of harassment, while not gendered in content, were directed only at female employees. The complaint alleges that Weinstein, a physically imposing man, "used his stature and threatening statements ... to demean and frighten female employees...yelling at them for purported incompetence, cursing in their faces, threatening to end their careers, and describing his intent to harm them, all while walking into them and bringing his

39. Garrahan, supra note 36 .

40. Chris Pleasance, 'Accusing Weinstein Ended My Career': Former Assistant Says She Ended Up Training Horses in Central America after Legal Fight with Shamed Media Mogul Left Her Reputation in Tatters, DAILY MAIL (Dec. 20, 2017), http://www.dailymail.co.uk/news /article-5196571/Weinstein-assistant-Accusing-ended-career.html [https://perma.cc/8LWPWCDP].

41. Verified Petition, People v. The Weinstein Co., No. 450293/2018 (N.Y. Sup. Ct. Feb. 11, 2018) [hereinafter Weinstein Complaint]; Press Release, A.G. Schneiderman Files Civil Rights Lawsuit Against the Weinstein Companies, Harvey Weinstein, and Robert Weinstein, N.Y. ST. OFF. OF THE ATT'Y GEN. (Feb. 11, 2018), https://ag.ny.gov/press-release/ag-schneidermanfiles-civil-rights-lawsuit-against-weinstein-companies-harvey $\quad[$ https://perma.cc/KV7Z$\mathrm{KK} 6 \mathrm{H}]$.

42. Weinstein Complaint, supra note 41 , at 7.

43. Id. at 9-10 ("H[arvey] W[einstein] regularly called female employees "cunt" or "pussy" when he was angry with them or felt they had done a task poorly or incorrectly, or even just instead of calling them by their first names.").

44. Id. at 10 .

45. Id. ("When Weinstein wanted to particularly degrade or scold men, he called them cunt or pussy as well .... He told one male assistant that he was firing him for being 'a fucking faggot boy, a stupid fucking faggot boy."). 
face only a few inches from theirs." ${ }^{46}$ He violently punched one employee's car seat, and backed her up against a wall while berating her. ${ }^{47} \mathrm{He}$ often told employees he would kill them or their families, saying he had contacts in the Secret Service and threatening, "You don't know what I can do." 48

Not only did Weinstein harass employees in sexual and nonsexual ways; he also systematically discriminated against female employees in assigned duties and expectations. According to the complaint, he threatened to fire some female assistants "if they did not serve in gendered roles such as providing childcare to his young children, obtaining [his] prescriptions for medicine, and performing other domestic labor such as assisting [his] wife or one of [his] adult daughters." ${ }^{49}$ Weinstein similarly expected female assistants and even female executives who were trained in film production to facilitate and hide his sexual liaisons - a role that male executives were not expected to fill. ${ }^{50}$ One beleaguered employee complained to human resources, stating she did "not appreciate being given work my male counterparts are never asked to complete." 51 When Weinstein berated her and retaliated against her, she left. ${ }^{52}$

Harvey Weinstein's behavior was extreme, but it illustrates the way harassment works generally. Not only did Weinstein make unwanted sexual overtures, he also routinely harassed and demeaned his employees in other ways that were rooted in sexism and stereotypes. In this regard, Weinstein was far from unusual. Decades of research shows that nonsexual forms of sexism and abuse, directed at women simply because they are women, are far more prevalent than unwanted sexual advances and sexual coercion. ${ }^{53}$ Indeed, according to one group of leading researchers, this nonsexual, but still sex-based harass-

\footnotetext{
46. Id. at 11 .

47. Id.

48. Id. at 12 .

49. Id. at 14 .

5o. Id. at 15 .

51. Id. at 14 .

52. Id.

53. See Berdahl \& Raver, supra note 32, at 641, 646 (describing studies); Chai R. Felblum \& Victoria A. Lipnic, Report of the Co-Chairs of the EEOC Select Task Force on the Study of Harassment in the Workplace, EQUAL EMP. OPPORTUNITY COMMISSION, nn.15 \& 19-20 (June 2016), https://www.eeoc.gov/eeoc/task_force/harassment/report.cfm\#_Toc453686302 [https:// perma.cc/Z2KP-77 CZ] (collecting recent studies). For one recent study, see Leskinen et al., supra note 18 , at 25,37 (reporting that for women in the military and in law, sex-based or "gender harassment in the absence of unwanted sexual attention or coercion was the most common manifestation of harassment," with nine out of ten victims facing such harassment).
} 
ment is not just a side story - it is the modal form of harassment against women in traditionally male-dominated job settings. ${ }^{54}$

\section{Silicon Valley}

While most of Weinstein's victims worked in traditionally female roles, many women who work in traditionally male jobs in similarly male-dominated industries have comparable experiences. The stories of engineer Susan Fowler and venture capital junior partner Ellen Pao illustrate how unwanted sexual advances reflect a larger culture of sexism, nonsexual harassment, and sex discrimination in the Silicon Valley technology industry.

For Susan Fowler, the engineer whose February 2017 blog post blew the lid off Uber's sexist work culture, ${ }^{55}$ the trouble began on the first day of work, when her manager sent her chat messages saying he was looking for a woman to have sex with. The pass itself was offensive, but what proved to be even more debilitating to her and other women at Uber was the company's failure to take their complaints and concerns - and the women themselves - seriously. ${ }^{56}$ Fowler's complaint about her manager's behavior, like those of women before her, fell on deaf ears: upper management declined to punish a "high performer," and the human resources department instead gave Fowler a "choice" to find a new team or expect a poor performance evaluation. ${ }^{57}$

When Fowler moved to a new team at Uber, the chaos and sexism there were so palpable that women fled in droves. Her director excused the exodus by saying the women "needed to step up and be better engineers," and a human resources manager suggested a low number of women should be expected in engineering "because sometimes certain people of certain genders and ethnic

54. Leskinen et al., supra note 18 , at 25 (showing that "gender harassment does not simply provide a backdrop for other kinds of harassment; it is the modal form of sex-based harassment faced by women at work ....").

55. Susan Fowler, Reflecting on One Very, Very Strange Year at Uber, SUSANJFOWLER.COM (Feb. 19, 2017) https://www.susanjfowler.com/blog/2017/2/19/reflecting-on-one-very-strange-yearat-uber [https://perma.cc/2EHY-7WC5].

56. For other accounts of widespread sexism at Uber, see Mike Isaac, Inside Uber's Aggressive, Unrestrained Workplace Culture, N.Y. TIMES (Feb. 22, 2017), https://www.nytimes.com/2017 /02/22/technology/uber-workplace-culture.html [https://perma.cc/S75B-8FXB]; Amy Vertino, I Am an Uber Survivor, MEDIUM (Feb. 24, 2017), https://medium.com/@amyvertino /my-name-is-not-amy-i-am-an-uber-survivor-c6d6541e632f [https://perma.cc/UR69UNC6].

57. Fowler, supra note 55 . 
backgrounds were better suited for some jobs than others[.]" 58 The company even went so far as to deny the women leather jackets that were provided to all the male engineers, saying there were too few women to justify placing an order. After being told she was "on thin ice" for reporting repeated problems to human resources and being threatened with firing, Fowler finally left Uber, like most of her other female colleagues. When she began working at Uber, women were twenty-five percent of her unit's engineers; by the time she left, that number had dwindled to three percent. ${ }^{59}$ At Uber, then, the initial sexual overture turned out to be only the first in a crushing series of discriminatory actions that conveyed how little women mattered to the company.

Ellen Pao's account of her problems as a junior partner at Kleiner Perkins Caufield \& Byers, a leading venture capital firm, similarly begins with a sexual overture. Like Fowler's, Pao's story ends up providing a larger window into the systematic disrespect and discrimination she and other women face in venture capital and the broader tech industry. ${ }^{60}$ On a trip abroad, a fellow junior partner told Pao that he was unhappily married and thought he and she would be "good together." He asked for her hotel room number, but when she mistakenly gave him the wrong one, he was angry the next day, having gone to the room for a rendezvous and not found her there. ${ }^{61}$ Over time, Pao succumbed to his entreaties and they had a brief affair. ${ }^{62}$

When she broke up with him, ${ }^{63}$ Pao alleges the man retaliated by sabotaging her career. For five years, according to Pao, her colleague excluded her from business meetings and emails, failed to share crucial job information with her, and tried to steal companies Pao sponsored. ${ }^{64}$ More than once, Pao complained to senior partners about this retaliatory harassment, but they did nothing. ${ }^{65}$ Instead, the firm promoted the man to senior partner in the group where she worked, giving him even more control over her career. ${ }^{66}$ After his promotion, Pao began receiving poor performance reviews. ${ }^{67}$ Pao later discovered that the man had sexually harassed another female junior partner-a fact that should
58. Id.
59. Id.
60. See Eluen Pao, Reset: My Fight For Inclusion and Lasting Change (2017).
61. Id. at 94 .
62. Id. at 96 .
63. Id. at 98 .
64. Id. at 112-13.
65. Id. at $111-12,123,126$.
66. Id. at 116.
67. Id. at 123 . 
have lent Pao's complaint more credibility-but reporting this discovery did not vindicate Pao's reputation or prospects at Kleiner Perkins. ${ }^{68}$ The firm did eventually let the alleged harasser go (reportedly with a generous severance package), ${ }^{69}$ but it also fired Pao and hired a public relations firm to discredit her throughout Silicon Valley. ${ }^{70}$

Pao's complaint and her later book make clear that the alleged sexual harassment and retaliation she faced was part of broader pattern of sexism and discrimination against women at Kleiner Perkins. Pao alleges that women were systematically excluded from events that presented business opportunities and subjected to rigged rules of the game that doomed them to failure from the start. There were male-only ski trips and dinners to which women were not invited because they would "kill the buzz,"71 practices that prevented women (but not men) from serving on the Boards of Directors for the companies they sponsored, ${ }^{72}$ and constant efforts to poach women's companies, especially when they were out on pregnancy leave. ${ }^{73}$ When Pao complained to her boss about these problems, he reportedly trivialized them or yelled at her and told her to drop it. ${ }^{74}$ Eventually, after realizing that the company was never going to change, Pao filed suit and was fired. ${ }^{75}$

It is Pao's description of the "thousand paper cuts," 76 the daily humiliations, exclusions, and slights that she and other women suffered at the hands of male higher-ups and peers at Kleiner Perkins, that most clearly reveals the ubiquity and scale of the harassment and discrimination women face in the technology industry generally. Highly educated female engineers and professionals were routinely assigned "domestic" tasks, such as taking notes at meetings, that were never asked of their male colleagues. ${ }^{77}$ As if that were not sufficiently demeaning, the women suffered myriad other acts of hostility and disrespect. In Pao's words:

\footnotetext{
68. Id. at 126-27, 129-135.

69. Id. at 131 .

7o. Id. at 135,151 .

71. See Emily Chang, Brotopia: Breaking up the Boys' Club of Silicon Valley 143 (2018); PAO, supra note 60 , at $124-25,128$.

72. PAO, supra note 60 , at $76-77,120-21,128$.

73. Id. at $117-18,145$.

74. Id. at 123,131 .

75. Id. at 135,151 .

76. Id. at 32; see also CHANG, supra note 71 , at 123 .

77. PAO, supra note 60 , at $88,127-28$.
} 
[Women] were often talked over and interrupted. When we were able to get a word in, we were ignored. If someone liked our ideas, they would repeat them and get credit .... Our annual performance reviews cast us as poor team players when we tried to claim credit for our work, and our reviewer lists were often stacked with people who were biased against us. We weren't invited to meetings, included on emails, asked to interview candidates, selected for hiring committees. We had the seats in the back of the room, the offices in the outer reaches, the nonspeaking roles at offsites and conferences. ${ }^{78}$

Not only were such sexist indignities rampant, according to Pao, but racist comments and interactions were also common occurrences. ${ }^{79}$ Despite their social invisibility, these microaggressions take their toll. ${ }^{80}$ It is little wonder, then, that the fate of the few women employed at Kleiner Perkins resembled that of Uber's female engineers. Three years after Pao was fired, every single woman she worked with as a junior partner had left or been forced out of the firm. ${ }^{81}$ Like their Uber counterparts, Kleiner Perkins's higher-ups attributed the decline not to sexism, but to women's biology, "maternal clocks," or "a burning desire to 'opt out'." 22

Fowler's and Pao's accounts demonstrate that unwanted sexual advances were only one manifestation of much larger problems at their technology companies. Below the surface lay broader patterns of sexism, exclusion, marginalization, and disrespect. Their experiences in this regard were, once again, not unusual. ${ }^{83}$ In a 2015 survey of women, most of whom work in Silicon Valley, $60 \%$ said they had been sexually harassed or experienced unwanted sexual ad-

78. Id. at 129; see also id. at 143 (detailing other microaggressions).

79. See, e.g., id. at 65-66 (recounting how her boss had specifically requested an Asian women for her job); id. at 86-87 (describing frequent jokes about how all Black and Latinx people were drug dealers and all Indians wore turbans, and comments conflating Asian names); $i d$. at 87 (relating how her boss constantly confused her with another Asian female); $i d$. at 88 (describing a "turban" joke in a fundraising meeting and having to apologize to an Indian limited partner); $i d$. at 89 (relating a comment about "Jewish lightning," a reference to setting fires on purpose to collect insurance money).

80. See Chang, supra note 71 , at 123 .

81. PAO, supra note 60 , at 153 .

82. Id. at 142 .

83. See, e.g., Chang, supra note 71 ; Liza Mundy, Why Is Silicon Valley So Awful to Women?, ATLANTIC (Apr. 2017), https://www.theatlantic.com/magazine/archive/2017/o4/why-is-silicon -valley-so-awful-to-women/517788 [https://perma.cc/54ZL-7EB3]. 
vances. ${ }^{84}$ But a whopping $90 \%$ reported witnessing sexist behavior, ${ }^{85} 88 \%$ had questions addressed to male colleagues that should have been addressed to them, ${ }^{86} 84 \%$ said they had been called too aggressive at work, ${ }^{87} 75 \%$ were asked about their family, marital status, or children in interviews, ${ }^{88} 66 \%$ felt excluded from networking activities because of their sex, ${ }^{89}$ and $59 \%$ said they had not received the same opportunities as their male counterparts. ${ }^{90}$ Moreover, almost half the women surveyed said they were asked to do menial tasks, like taking notes or ordering food, that men in their offices were not asked to do. ${ }^{91}$ In Silicon Valley, then, as in Hollywood, unwanted sexual advances are only one sign of an exclusionary culture that marginalizes women and preserves the industry as a bastion of masculine authority, competence, and identity. ${ }^{92}$

\section{B. Legal and Social Effects}

Focusing narrowly on sexual advances neglects these pernicious nonsexual, but still utterly sexist, forms of harassment, despite the fact that they cause similar professional and personal harms. ${ }^{93}$ Not only that, but having such a narrow focus actually helps insulate a great deal of harassment from legal and organizational responsibility. ${ }^{94}$ Like explicitly sexual forms of misconduct,

84. Trae Vassallo et al., ELEPHANT IN THE VALLEY (2015), https://www.elephantinthevalley.com [https://perma.cc/N2AV-WP6A].

85. Id.

86. Id.

87. CHANG, supra note 71 , at 118 ; Vassallo et al., supra note 84 .

88. Vassallo et al., supra note 84 .

89. Id.

9o. $I$ d.

91. Id.

92. See Pui-Wing Tam, How Silicon Valley Came to Be a Land of 'Bros', N.Y. Times (Feb. 5, 2018), https://www.nytimes.com/2018/o2/o5/technology/silicon-valley-brotopia-emily-chang .html [https://perma.cc/4K9K-H88X] (citing Emily Chang's book, Brotopia, supra note 71, for the idea that even the industry's "secret sex parties are just a symptom of a much deeper problem that Silicon Valley's tech industry has with the treatment of women").

93. For sources documenting the harms of nonsexual forms of harassment at work, see Leskinen et al., supra note 18, at 37. See also M. Sandy Hershcovis \& Julian Barling, Comparing Victim Attributions and Outcomes for Workplace Aggression and Sexual Harassment, 95 J. APPLIED PsYCHOL. 874, 874 (2010) ("Negative outcomes of workplace aggression were stronger in magnitude than those of sexual harassment for 6 of the 8 outcome variables.").

94. See Tristin K. Green, Was Sexual Harassment Law a Mistake? The Stories We Tell, 128 YALE L.J.F. 152, 161-69 (2018) (arguing that sexual harassment law has been constructed around 
nonsexual forms of misconduct are prohibited by employment discrimination law, if at all, only if they are considered harassment; there is no other claim of discrimination that covers them. ${ }^{95}$ In addition, exclusively highlighting the harm of sexual advances can make nonsexual forms of harassment look insignificant, leading decisionmakers to find them insufficiently severe to be actionable. ${ }^{96}$ Furthermore, reducing sexism to sexual harm can obscure the genderbased motivations underlying nonsexual acts of harassment. ${ }^{97}$ By the same token, ignoring evidence of nonsexual harassment can also exonerate unwanted sexual overtures, by considering them in isolation from broader patterns of discriminatory behavior and by making them appear trivial. Years ago, I demonstrated these harms of disaggregating sexual from nonsexual forms of harassment in the law. ${ }^{98}$ Despite some progress, these problems have not been fully resolved. ${ }^{99}$

Highlighting sexual harms does not just limit the legal system's response; it can also lead victims to underreport nonsexual acts of sex- and gender-based hostility. Indeed, without vigorous public education, many people will not even recognize that such acts are "sexual harassment" forbidden by law, policy, or social norms. ${ }^{100}$ For this reason, unlike with overtly sexual harassment, women and other victims may also be more likely to internalize and blame themselves for nonsexual harassment, rather than attributing it to sexism and gender bias for which they are not responsible. ${ }^{101}$

individual stories of sexual advances which then obscures how they are tied to broader hostile work environments and ultimately leads to overly narrow reforms).

95. As I explained in earlier work, both nonsexual and more sexual forms of harassment that do not amount to or culminate in a tangible employment decision, such as firing or demotion, are not typically covered as ordinary disparate treatment. Thus, to be actionable, they must be considered harassment, a form of discrimination in the "terms and conditions" of employment. See Schultz, supra note 1, at 1714-16; see also Oncale v. Sundowner Offshore Servs., Inc., 523 U.S. $75,79-80$ (1998).

96. See Schultz, supra note 1 , at 1710-13, 1722-29.

97. Id. at $1748-55$.

98. Id. at 1720-29; see also id. at 1729-32.

99. See, e.g., Vicki Schultz, Open Statement on Sexual Harassment from Employment Discrimination Law Scholars, 71 STAN. L. REV. ONLINE 17, 20-21 (2018) (citing continuing problems); David J. Walsh, Small Change: An Empirical Analysis of the Effect of Supreme Court Precedents on Federal Appeals Court Decisions in Sexual Harassment Cases, 1993-2005, 30 Berkeley J. EMP. \& LAB. L. 461, 463 (2009); Eleanor Frisch, Note, State Sexual Harassment Definitions and Disaggregation of Sex Discrimination Claims, 98 MinN. L. Rev. 1943 (2014).

100. Kathryn J. Holland \& Lilia M. Cortina, When Sexism and Feminism Collide: The Sexual Harassment of Feminist Working Women, 37 PSYCHOL. WOMEN Q. 192, 193 (2013) (citing studies).

101. See generally Hershcovis \& Barling, supra note 93, at 874 (showing that victims of sexual harassment were more likely than those of workplace aggression to depersonalize their mis- 
A poignant example of these problems can be found in the way Harvey Weinstein's employees were viewed by many people in the film industry and the press. Under the older view of harassment as sexual predation, Weinstein's only real sins were his sexual advances against women seeking roles in his films. If harassment is limited to "eroticized" behavior, as one source put it, the only true victims are "those who have alleged intense sexual harassment, assault, and rape." 102 This perspective exonerated Weinstein's nonsexual harassment of his employees, portraying them as co-conspirators complicit in luring in victims and covering up sexual misconduct rather than as victims of harassment and discrimination in their own right. ${ }^{103}$ Indeed, after the Weinstein story broke, this view was so prevalent that Weinstein's staff felt compelled to publish a statement defending themselves from accusations of collaboration. ${ }^{104}$ Under the old view of harassment, then, the very possibility that these employees had themselves suffered sex-based mistreatment was erased, making it impossible to even ask whether Weinstein's legendary bullying was in fact part of a larger pattern of sex bias and misogyny. It was not until the New York Attorney General's lawsuit helped reframe harassment and discrimination in broader terms, alleging that Weinstein engaged in sexual, nonsexual, and same-sex harassment and discrimination against his male and female employees, ${ }^{105}$ that these employees were revealed as additional victims.

treatment and attribute blame to the perpetrator's sexism, even though workplace aggression may also have been motivated by gender hostility); $i d$. at 883 (reporting that outcomes for workplace aggression were stronger in magnitude than those for sexual harassment on six of eight outcome variables); Deborah Lee, Gendered Workplace Bullying in the Restructured UK Civil Service, 31 PERSONNEL Rev. 205, 206 (2002) (showing how acts of aggression often understood to be instances of bullying or general hostility are actually gender-based because they are rooted in gender-based expectations for proper workplace behavior).

102. Dana Goodyear, Harvey Weinstein's Former Employees Reckon with What They Knew and What They Didn't, New YoRKer (Oct. 19, 2017), https://www.newyorker.com/news/news-desk / harvey-weinsteins-former-employees-reckon-with-what-they-knew-and-what-they-didnt [https://perma.cc/S 3 ED-PRUH]; see also $i d$. (quoting Catharine MacKinnon for the idea that harassment is "dominance eroticized").

103. See id.

104. Statement from Members of the Weinstein Company Staff, NEW YORKER (Oct. 19, 2017), https://www.newyorker.com/news/news-desk/statement-from-members-of-the-weinstein -company-staff [https://perma.cc/2PUE-2HUB] ("We all knew that we were working for a man with an infamous temper. We did not know we were working for a serial sexual predator.").

105. See supra notes $42-52$ and accompanying text. 


\section{Theoretical Implications}

Not only is it inexcusable to erase the harms of nonsexual forms of harassment, but ignoring them also leads to an inadequate view of the dynamics driving harassment generally. Once we acknowledge that most harassment does not take the form of sexual overtures, it becomes clear that harassment is not and cannot be primarily a means of expressing sexual desire or sexual domination. Most of the time, harassment is not about securing sexual gratification; it's about putting women (and men who are "not man enough") down, reinforcing the existing gender order, and reaffirming threatened social identities. This happens in many realms of life, but nowhere is it more pronounced than in work or career-related settings.

For most American men, historically, labor market and workplace superiority has been crucial to hegemonic masculine identity. ${ }^{106}$ Earning more than comparable women, holding a traditionally male job, and possessing skills and authority that women allegedly lack are all central to mainstream masculinity. ${ }^{107}$ Thus, it is unsurprising that women who enter traditionally maledominated work settings are more likely to experience sex-based harassment than other women. ${ }^{108}$ Research shows this is not simply because these women are more likely to encounter men. Rather, it is because they pose a threat to the masculine composition and image of the men's jobs and to their sense of manhood. ${ }^{109}$

106. Hegemonic masculinity is defined as the most favored view of manhood in a particular context, and the one to which all men experience pressure to conform. It is premised on and promotes the exclusion of women and a rank ordering of men. For a clear elaboration of the concept, see David S. Cohen, Keeping Men "Men" and Women Down: Sex Segregation, AntiEssentialism, and Masculinity, 33 HARV. J.L. \& GENDER 509, 523-25 (2010) (explaining hegemonic masculinity and collecting classic sources).

107. Schultz, supra note 1, at 1758; see also Vicki Schultz, Life's Work, 100 COLUM. L. ReV. 1881 1886-92 (2000) (discussing the importance of wage work to the American sense of citizenship and identity, historically).

108. Berdahl, supra note 18, at 647 (collecting studies); Dana Kabat-Farr \& Lilia M. Cortina, SexBased Harassment in Employment: New Insights into Gender and Context, 38 LAW \& HUM. BEHAV. 58, 67-68 (2014). See generally James Gruber, The Impact of Male Work Environments and Organizational Policies on Women's Experiences of Sexual Harassment, 12 GENDER \& SOC'Y 301 (1998).

109. Berdahl, supra note 18, at 649; Kabat-Farr \& Cortina, supra note 108, at 68; Schultz, supra note 1 , at 1762 . Research has found, for example, that women who work in jobs traditionally sex-typed as masculine and women with more "masculine" as opposed to traditionally feminine ways of presenting themselves both experience more harassment in male-dominated job settings. See Berdahl, supra note 31, at 429, 433. Additionally, women with feminist ambitions to enter high-paying and traditionally male fields on equal terms experience more 
Importantly, it is not only cisgender women who experience such harassment. Both homosexual and heterosexual men who fail to conform to prescribed images of how "real men" are supposed to look and behave are also frequently harassed in these settings. ${ }^{110}$ Lesbians, bisexuals, transgender, and nonbinary people also experience disproportionately high rates of workplace harassment, ${ }^{111}$ as do women of color. ${ }^{112}$ These groups are frequently stereotyped and perceived as challenging prevailing gender arrangements; their presence as equals threatens the workplace gender hierarchy and the superior occupational status and social identities of dominant groups.

Once harassment is understood as a means of protecting hegemonic masculine work status and identity, even unwanted sexualized attention becomes visible as a means of putting women, gender-nonconforming men, and others who fail to conform to traditional gender expectations in their place. Research confirms that unwanted sexual advances and coercion do not occur in isolation, but typically occur in combination with sex-based or other generalized harass-

harassment in mostly-male job settings. See Anne Maass et al., Sexual Harassment Under Social Identity Threat: The Computer Harassment Paradigm, 85 J. Personality \& Soc. Psychol. 853 (2003). Meanwhile, women who supervise men similarly suffer higher rates of harassment, as some men refuse to bow to the authority of a female. See Heather McLaughlin et al., supra note 31 , at 632 ("Female supervisors are 138 percent more likely to experience any harassing behaviors, [and] they report a rate of harassment 73 percent greater than that of nonsupervisors.").

110. See Ann C. MCGinley, Masculinity at Work: EmPloyment Discrimination through a DifFERENT LENS (2016) (describing the harassment of men who fail to conform to dominant male workers' expectations for masculinity); Schultz, supra note 1, at 1774-89 (same); see also Jennifer L. Berdahl \& Sue H. Moon, Workplace Mistreatment of Middle Class Workers Based on Sex, Parenthood, and Caregiving, 69 J. Soc. Issues 341 (2013) (showing that fathers who spend too much time caring for their children are more likely to be harassed than other men).

11. See, e.g., Jaime M. Grant et al., Injustice at Every Turn: A Report of the National Transgender Discrimination Survey, CtR. FOR Transgender EQUality \& NAT'L Gay \& Lesbian Task FORCE 51 (2011), http://www.thetaskforce.org/static_html/downloads/reports/reports/ntds full.pdf [https://perma.cc/KGT8-BNA7] (reporting that 90 percent of transgender or gender nonbinary people surveyed had experienced harassment, mistreatment, or discrimination on the job or had taken actions to avoid this treatment); Christy Mallory \& Brad Sears, Documented Evidence of Employment Discrimination \& Its Effects on LGBT People, WILLIAMS INSTITUTE (2011), http://williamsinstitute.law.ucla.edu/wp-content/uploads/SearsMallory-Discrimination-July-20111.pdf [https://perma.cc/CS6F-VTNZ] (reporting results of studies on workplace harassment and discrimination against LGBT people).

112. Jennifer L. Berdahl \& Celia Moore, Workplace Harassment: Double Jeopardy for Minority Women, 91 J. APPLIED PsYCHOL. 426, 432 (2006); McLaughlin et al., supra note 31, at 630 (collecting studies). 
ment, ${ }^{113}$ suggesting motivations beyond a desire for sexual gratification even for sexualized harassment. Furthermore, men who endorse stereotypical gender roles are more prone to harass women through sexual ${ }^{114}$ and nonsexual means, ${ }^{115}$ again suggesting motivations beyond sexual desire.

Based on this and other research, modern theorization rejects sexual desire or a desire for sexual domination as the best explanation for sexual harassment. ${ }^{116}$ Most of the time, the problem is not that harassers are individual perverts or "creeps" 117 who abuse their work positions to get sex. ${ }^{118}$ Instead, they are industry kingpins or workplace dominants who use sex and other "technologies of sexism" to reinforce their organizational and social positions. From the perspective of the harassers, demanding sexual favors is no different from other sexist demands: regardless of whether a boss pressures female employees to tolerate sexual misconduct, to suffer his angry tirades, to serve food or clean up at work, to take notes or "tone down" their behavior, to endure being ignored and interrupted, to sit in the back and avoid the limelight, or to attend to his personal needs, these are all patronizing, sex-based demands that preserve gender hierarchy and remind women of their proper place. If harassment is defined narrowly in terms of sexual overtures, this sexist, demeaning behavior disappears from view.

A broader theoretical lens makes it possible to see that ultimately, what is at stake for harassers is maintaining a sense of masculine prerogative and status in and through their work - one that depends on displaying mastery and superiority over women, and denigrates men they do not consider "real" men. From

113. See, e.g., Berdahl \& Raver, supra note 32, at 646 (collecting studies showing that unwanted sexual attention and sexual coercion co-occurs with gender-based harassment, as well as with other types of harassment); Fitzgerald et al., supra note 32; Lim \& Cortina, supra note 32.

114. See generally John B. Pryor, Sexual Harassment Proclivities in Men, 17 SEX RoLES 269 (1987).

115. See Berdahl, supra note 31 , at 429 (showing that women with relatively masculine personalities experience the most sexual harassment); Maass et al., supra note 109.

116. See, e.g., Ackerloff \& Kranton, supra note 18; Berdahl, supra note 18; Kabat-Farr \& Cortina, supra note 108.

117. See William Wan, What Makes Some Men Sexual Harassers? Science Tries to Explain the Creeps of the World, WASH. POST (Dec. 22, 2017), https://www.washingtonpost.com/news /speaking-of-science/wp/2017/12/20/what-makes-some-men-sexual-harassers-sciencetries-to-explain-the-harvey-weinsteins-of-the-world/?utm_term=.b1f5c3fie16a [https://perma.cc/ML6F-XHG9].

118. See e.g., Mike Fleming, Jr., How Male-Dominated Hollywood Contributes to Harassment Culture: Oscar-Winning Producer Cathy Schulman Explains, DEADLINE (Mar. 2, 2018), http://deadline.com/2018/o3/hollywood-male-dominated-cathy-schulman-interviewmetoo-times-up-women-in-film-progress-1202308160 [https://perma.cc/E6 $\mathrm{T}_{3}$-5 PKT]. 
this perspective, harassing other people and getting away with it confirms and even enhances their superior status. Organizational tolerance, coverups, and nondisclosure agreements become just another sign of their hyper-masculine workplace success and stardom. ${ }^{119}$ As Harvey Weinstein's former assistant Zelda Perkins put it: "I don't think he's a sex addict. He's a power addict.... With Harvey, there was no such word as no."120

\section{FOUNDATIONS}

To have an adequate theory of harassment, it is not enough to understand what the harassers stand to gain. It is even more important to understand the industry dynamics and organizational conditions that foster and fuel harassment.

There are many such factors, ${ }^{121}$ but here I will stress two structural features of industries and fields in which harassment is known to flourish: sexsegregated work and subjective, unconstrained authority. My earlier work emphasized the importance of sex segregation to harassment, focusing primarily on peer harassment. ${ }^{122}$ But in considering the many reports from the \# MeToo movement that involve harassment by highly positioned men, and in analyzing the question of organizational power, I have come to appreciate the importance of the second factor as well.

On closer inspection, it is no accident that Hollywood and Silicon Valley are rife with harassment. Both industries are characterized by a high degree of sex segregation, where mostly men hold leadership positions and favored jobs, while women are greatly outnumbered or are concentrated in less highlyregarded roles. Similarly, both industries grant executives and managers vast unchecked subjective discretion to hire and promote people; success depends on navigating informal social networks and impressing high-status kingmakers who have the subjective authority to make or break careers and life prospects.

119. See id. (reporting the views of Cathy Schulman, Oscar-winning film producer and president of Women in Film, on the connections between entrenched sexism in Hollywood, the prevalence of powerful men harassing women, and "bullying tactics, payouts, and non-disclosure agreements").

120. Longeretta, supra note 36 .

121. Schultz, supra note 99 , at 41-46 (identifying the structural vulnerability of workers and a lack of fair and equal access to the legal system as additional risk factors); Feldblum \& Lipnic, supra note 53 (identifying several risk factors for sexual harassment, including lack of diversity, gender nonconformity, isolated workspaces, customer-drive compensation, alcoholconsuming cultures, decentralized authority, and significant power disparities).

122. See, e.g., Schultz, supra note 1 , at 1756-1761; Schultz, supra note 2, at 2139-2144. 
These factors - sex segregation and unconstrained, personalistic authority - set the stage for sexual harassment.

\section{A. Sex Segregation}

The sex segregation of work is both a cause and consequence of harassment. ${ }^{123}$ Sex segregation means men hold the most powerful or prized jobs, while women hold lower-status positions. This state of affairs fosters sex stereotypes - for example, a sense that men are leaders or geniuses while women are followers,. Segregation primes these stereotypes, prompting the dominant group to perceive any minorities who enter their jobs as "different" and out of place, and to close ranks against them to defend their position and status. Because men's work roles still tend to afford them higher status, men's stake in preserving their superior workplace positions and associated masculinities is typically stronger than women's in preserving traditionally female jobs and related femininities. For this reason, men are more likely than women to engage in harassment and more likely to do so when they work in traditionally maledominated settings, as discussed above. ${ }^{124}$

Sex segregation also makes it more difficult for those in the minority to resist harassment. Without the power and safety that comes with more equal numbers, women and others who are harassed cannot effectively censor or counter stereotypes and cannot effectively deter, resist, or report harassment. Nor can they participate effectively in shaping the organization's cultures and norms, or in changing the organization's structures and practices in ways that foster greater inclusion and equality. Research shows that skewed numbers leave women outnumbered and vulnerable at work, left to curry favor or compete with men on an unequal basis. ${ }^{125}$

Harassment, in turn, further fuels sex segregation and stereotyping. By driving women away or discouraging them from male-dominated fields, and

123. For extended theoretical discussions of the relationship between sex-segregation and sexbased harassment that make these points, see Schultz, supra note 1, at 1756-60; Schultz, supra note 2, at 2132-36, 2139-45, 2173-77.

124. Berdahl, supra note $\mathbf{3 1}$, at 433 .

125. See Schultz, supra note 2, at $2143 \mathrm{nn} .328-29$ \& accompanying text; see also ROSABETH MOSS Kanter, MEN and Women of the Corporation 206-44 (1977); Iris BoHnet, What Works: GeNDER EQUality BY Design 211-12, 230-33, 349 (2016); Robin J. Ely, The Effects of Organizational Demographics and Social Identity on Relationships Among Professional Women, 39 ADMIN. SCI. Q. 203, 224-30 (1994); and Belle Derks et al., The Queen Bee Phenomenon: Why Women Leaders Distance Themselves from Junior Women, 27 LEADERSHIP Q. 456, 458-460, 464 (2016). 
labeling the women who pursue them as different and less capable, harassment reinforces both horizontal and vertical segregation ${ }^{126}$ and confirms perceptions that women are not suited for traditionally "masculine" jobs or leadership roles. Similarly, by pressuring women in traditionally female-dominated jobs to tolerate sexist demands, harassment reinforces vertical sex segregation by confirming ideas that women do and should naturally submit to male authority. Thus, segregation and harassment reinforce each other in a selfperpetuating cycle.

\section{B. Unconstrained, Subjective Authority}

It is not only the gendered nature of the hierarchy that fuels harassment: it is also the nature of the hierarchy itself. Harassment is fueled by employment systems that give higher-ups unchecked, subjective authority to make or break other people's careers on their own subjective say-so, without the use of objective criteria or external oversight to constrain their judgments.

By unconstrained, subjective authority, I refer to the use of subjective selection systems for hiring, assigning, promoting, paying, firing, and evaluating people. ${ }^{127}$ First, these systems vest broad discretion in individual executives, managers, or supervisors to evaluate people based on their own personal judgment, free from external oversight or accountability. In addition, these systems are often subjective in the sense that managers deploy unmeasurable, nonobjective criteria, such as "leadership potential" or "cultural fit." Furthermore, even if some managers rely on objective criteria, the selection process may still be subjective in another sense, namely a lack of uniformity or consistency. Subjective systems typically make little or no effort to ensure that all managers use the same criteria to assess candidates or that they weigh or apply those criteria in the same way to all candidates. The result of all these factors is a lack of transparency, for candidates cannot ascertain in advance what it takes to succeed in these systems. These systems sometimes also involve an additional dimension of subjectivity: the use of tightly knit social networks to recruit and attract new talent. These networks privilege the subjective judgment of not just one executive or manager, but multiple industry insiders or peers, to rec-

126. See Schultz, supra note 2, at $2140-43$ (explaining how both horizontal sex segregation, the tendency of men and women at similar organizational levels to work in different jobs, and vertical sex segregation, the tendency of women to be concentrated in lower-level positions supervised by men, both encourage harassment).

127. For a description of subjective employment decisionmaking, see David L. Rose, Subjective Employment Practices: Does the Discriminatory Impact Analysis Apply?, 25 SAN Diego L. ReV. 63, 68-69 (1988). 
ommend candidates based on their reputations or social connections. Finally, the term unconstrained, subjective authority can refer not only to subjective hiring and evaluation, but also to the unfettered authority to direct and control the day-to-day work and activities of subordinates.

It is well known that unconstrained, subjective selection systems foster discrimination. Research demonstrates that processes that give managers unfettered discretion to make decisions about employees or aspirants based on their own subjective judgment facilitate stereotyping and discrimination. ${ }^{128}$ Psychological research further shows that people, such as managers, whose positions give them a high degree of power to affect other people's lives by providing or withholding resources or administering punishments are more prone to engage in stereotyping, because they are less likely to attend to individuating information about them. ${ }^{129}$ For these reasons, the law has long recognized that without objective guideposts or oversight to ensure candidates are treated evenhandedly, managers in subjective systems often fall back on stereotypes and bias in making employment decisions. ${ }^{130}$ Managers in these systems also tend to hire people who look like themselves to reduce uncertainty and foster trust. ${ }^{131}$ Where employment systems lack more defined ways to evaluate skill, moreover, candidates often must depend on tight social networks to acquire jobs and advance their careers. It is well known that these networks, too, often operate to exclude women and other outsiders. ${ }^{132}$

128. See, e.g., William T. Bielby, Minimizing Workplace Gender and Racial Bias, 29 CONTEMP. SOC. 120, 123 (2000) (citing research confirming this point); Barbara F. Reskin \& Debra Branch McBrier, Why Not Ascription? Organizations' Employment of Male and Female Managers, 65 AM. Soc. ReV. 210, 210-12 (2000); Vincent J. Roscigno et al., Social Closure and Processes of Race/Sex Employment Discrimination, 609 ANNALS AM. ACAD. POL. SCI. 16, 28-32 (2007).

129. See Dacher Keltner et al., Power, Approach, and Inhibition, 110 Psychol. REv. 265, 267, 273 (2003) (collecting studies).

130. See, e.g., Rowe v. Gen. Motors Corp., 457 F.2d 348, 359 (5th Cir. 1972) ("recogniz[ing] that promotion/transfer procedures which depend almost entirely upon the subjective evaluation and favorable recommendation of the immediate foreman are a ready mechanism for discrimination"). For additional cases, see Schultz, supra note 8, at 1063 n.364.

131. For the classic study, see KANTER, supra note 125, at 48-63 (discussing how managers resort to "homosocial reproduction" to reduce uncertainty); see also James N. Baron et al., In the Company of Women: Gender Inequality and the Logic of Bureaucracy in Start-Up Firms, 34 WORK \& OCCUPATIONS 35 (2007); Roscigno et al., supra note 128; Natalie Wreyford, Birds of a Feather: Informal Recruitment Practices and Gendered Outcomes For Screenwriting Work in the UK Film Industry, 63 SOC. REV. 84 (2015).

132. See, e.g., Ronald S. Burt, The Gender of Social Capital, 5 Rationality \& Soc. 10 (1998); Mia Gray et al., Networks of Exclusion: Job Segmentation and Social Networks in the Knowledge Economy, 144 Equal OpPoRTUNiTIES INT'L 26 (2007); Mark Lutter, Do Women Suffer from Network Closure? The Moderating Effect of Social Capital on Gender Inequality in a Project-Based 
Here I extend these older observations to offer a new insight: just as unfettered, subjective authority facilitates discrimination in hiring and promotion, it also fosters sex-based harassment. This is true for two different reasons. First, giving higher-ups the authority to hire, promote, and fire people based on their own subjective judgment increases their power to exercise arbitrary and abusive authority over employees. Employees have no basis for demanding accountability in the absence of any objective standards or opportunity for oversight, especially in the typical at-will employment scenario. ${ }^{133}$ Industry cultures in which career advancement turns on connections rather than more objective credentials only intensify the problem, because they give higher-ups even more power to blackball those who cross or displease them.

But the problem is not simply that positions characterized by unchecked authority permit harassment and abuse; it is that they actually encourage it. Research shows that the nature of the authority vested in such positions inculcates in those who occupy them a sense of entitlement to wield arbitrary authority over people "beneath" them, simply by virtue of the fact that their positions give them the power to do so. ${ }^{134}$ In one classic study, managers vested with institutional power to control employees' behavior (by firing or demoting them and paying them less) increased their attempts to control subordinates, devalued subordinates' work efforts and performance, viewed them as objects of manipulation, and desired greater social distance from them. ${ }^{135}$ This study laid the groundwork for a metamorphic theory of power, "which asserts that through the repeated exercise of power individuals adopt more vainglorious self-concepts and as a consequence [come to] denigrate the less powerful."136 Unchecked institutional authority, in other words, begets a growing sense of personal power and self-aggrandizement. Both formal and informal sources of authority over others can feed this sense of power. ${ }^{137}$

Labor Market, 1929-2010, 80 AM. Soc. Rev. 329 (2015); Gail McGuire, Gender, Race, Ethnicity and Networks: The Factors Affecting the Status of Employees' Network Members, 27 WORK \& OCCUPATIONS 501 (2000).

133. See generally Private Government: How Employers Rule Our Lives (and Why We DON'T TALK ABOUT IT), at 37 (Elizabeth Anderson ed., 2017); Rachel Arnow-Richman, Of Power and Process: Handling Harassers in an At-Will World, 128 YALE L.J.F. 85 (2018) (arguing that at-will employment, employer contracting practices, and sexual harassment law combine to produce a world in which employers tolerate sexual harassment by top-level employers).

134. Keltner et al., supra note 129, at 266.

135. See David Kipnis, Does Power Corrupt?, 24 J. Personality \& Soc. Psychol. 33 (1972).

136. Keltner et al., supra note 129 , at 266.

137. See Jeanette N. Cleveland and Melinda E. Kerst, Sexual Harassment and Perceptions of Power: An Under-Articulated Relationship, 42 J. VOCATIONAL BEHAV. 49, 55-57 (1993) (explaining the 
At one level, these insights simply reflect the truism that sexual harassment is about power. But what is lacking in that observation is a specification of the nature and source of that power. Men's power in the workplace is not merely attributable to higher levels of testosterone or patriarchal conditions in society at large, as is often claimed. ${ }^{138}$ Instead, it is attributable to the unchecked, subjective authority that is vested in many men's organizational positions by companies, industries, and the law. As Donald Trump put it, "when you're a star, they let you do it. You can do anything." 139 Leading the Trump Organization, the Miss Universe pageant, and The Apprentice are what put him in the position of being a "star," not simply being male in a sexist society. Positions that grant people such unfettered subjective authority foster discrimination, harassment, and abuse.

\section{Contemporary Examples}

Together, then, sex segregation and unchecked authority shape industries and workplaces in ways that actively encourage harassment and disable victims from stopping it. The result is that too many men simply have too much unfettered authority to make or break the careers of the people who depend on them for their livelihoods and job prospects. Where both factors are present, they create a perfect storm for sexual harassment, as illustrated by Hollywood and Silicon Valley.

\section{Hollywood}

The Hollywood film industry is highly segregated by sex. Women are grossly underrepresented in all important behind-the-scenes roles in major film. Although women are around half of film school students, in 2016 women made up only $7 \%$ of all directors of the top 250 grossing films and only $17 \%$ of

sources of informal power male employees can exercise over female peers); see also Schultz, supra note 1 , at 1751-52, 1764-65 (showing how male workers who have the ability to informally train, inform, or otherwise affect the work performance of their female peers acquire power over them).

138. See Noah Berlatsky, It's Time to Stop Worshipping Powerful Men, QUARTz (Oct. 14, 2017), https://qz.com/1102376/its-time-to-stop-worshipping-powerful-men [https://perma.cc/FK 72-7MZZ].

139. Transcript: Donald Trump's Taped Comments About Women, N.Y. TIMES (Oct. 8, 2016), https://www.nytimes.com/2016/10/o8/us/donald-trump-tape-transcript.html [https://perma.cc/GD59-2RG5]. 
all behind-the-scenes roles on those films - figures that dropped from 2015. ${ }^{140}$ Women made up only $24 \%$ of producers, $17 \%$ of editors and executive producers, $13 \%$ of writers, $5 \%$ of cinematographers, and $3 \%$ of composers. ${ }^{141}$ The figures for female directors are even bleaker than they appear, because the studios hire the same women on a repeat basis. Among the goo top grossing films between 2007 and 2016, there were only thirty-four unique female directors. Only three were Black. ${ }^{142}$

Women also fare worse than men on screen. They garner fewer lead roles and fewer speaking roles overall. When they do appear in film, they play more sex-stereotyped and auxiliary roles. Women claimed lead roles in only twentynine percent of the top 168 films for $2015,{ }^{143}$ and only thirty-four percent of the top 100 films of 2016. ${ }^{144}$ This on-screen inequality is traceable, at least in part, to the dearth of women in key decisionmaking and behind-the-scenes roles. A growing body of evidence demonstrates that women's speaking roles increase dramatically as the number of women in directing roles increases. ${ }^{145}$

Not only is the film industry highly sex-segregated, but it also runs on unconstrained, subjective authority and reputational capital. From the studio executives and producers downward, Hollywood vests enormous, unchecked discretion in mostly male decisionmakers to hire the talent to produce and distribute films. For example, the major studios and talent agencies use secret

140. Martha M. Lauzen, The Celluloid Ceiling: Behind-the-Scenes Employment of Women on the Top 100, 250, and 500 Films of 2016, CTR. FOR StUdy WOMEN TELEVISION \& Film 1 (2017), https://womenintvfilm.sdsu.edu/wp-content/uploads/2017/o1/2016_Celluloid_Ceiling _Report.pdf [https://perma.cc/V97R-QPMC]; Shauna Murphy, Half of Film School Grads Are Women-So Why Are 1.9\% Directing Big Budget Films?, MTV News (May 13, 2015), http://www.mtv.com/news/2159771/female-directors-college/ [https://perma.cc/NR2HBYLC]; Malina Saval, Film Schools Open Path to Hollywood Diversity, VARIETY (Apr. 27, 2016), https://variety.com/2016/film/spotlight/film-schools-diversity-hollywood-12017609 91/ [https://perma.cc/9SSS-K5TF].

141. Lauzen, supra note 140 , at 2-3.

142. Stacy L. Smith et al., Inequality in 900 Popular Films: Examining Portrayals of Gender, Race/Ethnicity, LGBT, and Disability from 2007-2016, MEDIA, DIVERSITY \& SOC. CHANGE INITIATIVE, USC ANNENBERG 4 (July 2017), https://annenberg.usc.edu/sites/default/files/Dr _Stacy_L_Smith-Inequality_in_90o_Popular_Films.pdf [https://perma.cc/8DTF-SXBW].

143. 2017 Hollywood Diversity Report: Setting the Record Straight, RALPH J. BUNCHE CTR. FOR AFRICAN AM. STUD. UCLA 11 (2017), http://bunchecenter.ucla.edu/wp-content/uploads/sites/82 /2017/o4/2017-Hollywood-Diversity-Report-2-21-17.pdf [https://perma.cc/7VUD-R3J4].

144. Smith et al., supra note 142, at 1.

145. See, e.g., Stacy L. Smith et al., Exploring the Careers of Female Directors: Phase III, MEDIA, DIVERSiTy \& SOC. ChANGe INITIATIVE, USC ANNENBERg 9-10 (2015), https://annenberg.usc .edu/sites/default/files/MDSCI_2015Female_Filmmakers.pdf [https://perma.cc/P6U6EFVX]. 
lists and closed social networks to initially screen directors. ${ }^{146}$ It is well documented that these mechanisms disadvantage women. ${ }^{147}$ In one recent study, studio executives and agents who were asked to name people on the lists frequently failed to name any women directors. ${ }^{148}$ In addition, the subjective criteria and processes for assessing talent encourage studios to fall back on stereotypes. Studios envision film directors as commanding and inherently masculine, and presume that women lack the inclination or ability to direct films, particularly those in high-budget genres. ${ }^{149}$ The high degree of financial risk and uncertainty involved in filmmaking and distribution exacerbates these problems, leading filmmakers and funders to reject female directors or restrict them to "women's films." ${ }^{150}$ Similar considerations dictate casting decisions for actors, encouraging the use of race- and sex-stereotyped "breakdowns" and choices by studio executives, producers, directors, and writers, who themselves remain overwhelmingly white and male. ${ }^{151}$

The authority vested in studio executives and filmmakers to hire and direct talent has fostered widespread abuse; the tyrannical and predatory Hollywood boss has long been both an American legend and a lived reality. ${ }^{152}$ According to

146. See Letter from Melissa Goodman, Dir., LGBTQ, Gender \& Reprod. Justice Project, ACLU of S. Cal., to Anna Y. Park, Reg'l Att'y, EEOC L.A. Dist. Office (May 12, 2015), https://www .aclusocal.org/sites/default/files/wp-content/uploads/2015/05/EEOC-FINAL-LETTER-0511-2015.pdf [https://perma.cc/PDE5-NVRB] [hereinafter ACLU Letter].

147. See, e.g., Denise D. Bielby, Gender Inequality in Culture Industries: Women and Men Writers in Film and Television, 51 SOCIOLOGIE DU TRAVAIL 237, 248-49 (2009); William T. Bielby \& Denise D. Bielby, Cumulative Versus Continuous Disadvantage in an Unstructured Labor Market: Gender Differences in the Careers of Television Writers, 19 WORK \& OCCUPATIONS 366 (1992); Lutter, supra note 132; Wreyford, supra note 131; Stephen Zafirau, Reputation Work in Selling Film and Television: Life in the Hollywood Talent Industry, 31 QUAL. Soc. 99, 123 (2008).

148. Smith et al., supra note 145 , at 18 .

149. $I d$. at 4-5 (" $[\mathrm{O}]$ ne explanation for [female directors being perceived to make films for a less significant portion of the marketplace than men] is the tendency to "think director, think male," or to describe the job of a director or profitable film content in masculine terms.").

150. ACLU Letter, supra note 146, at 5-9.

151. Russell K. Robinson, Casting and Caste-ing: Reconciling Artistic Freedom and Antidiscrimination Norms, 95 CALIF. L. ReV. 1, 6-14 (2007).

152. See Richard Brody, Harvey Weinstein and the Illusion of the Vulgar but Passionate OldHollywood Studio Boss, New YoRKER (Oct. 17, 2017), https://www.newyorker.com/culture /richard-brody/harvey-weinstein-and-the-illusion-of-the-vulgar-but-passionate-old-holly wood-studio-boss [https://perma.cc/3 $\left.\mathrm{U}_{5} \mathrm{~L}-\mathrm{H}_{39} \mathrm{~L}\right]$; see also Phil Breman, The Hollywood Assistant Survival Guide, BALANCE CAREERS (Apr. 14, 2018), https://www.thebalance.com/film -tv-careers-the-hollywood-assistant-survival-guide-1283533 [https://perma.cc/M7R8-5V2L] (acknowledging the reality of "bosses who scream at, throw things, berate or just love to outright humiliate underlings"). 
a wide array of sources, discrimination and harassment are endemic in the industry. To change this situation requires appreciating its institutional foundations, rather than attributing these problems to individual pathology or generic patriarchy.

\section{Silicon Valley}

Like the Hollywood film industry, the Silicon Valley technology industry is sex-segregated and characterized by top-down, subjective decisionmaking. Commentators have drawn parallels between the problems for women in these two industries. ${ }^{153}$

For years, women have been underrepresented in leadership and prized technical roles in Silicon Valley. Given the industry's historic resistance to disclosing diversity-related data, ${ }^{154}$ definitive numbers are hard to come by. In 2013, engineer Tracy Chou posted on Medium asking people to share their companies' data. ${ }^{155}$ Pressure for transparency followed, and some companies finally began to release data. ${ }^{156}$ In 2014, women held only $17 \%$ of the technical jobs at Google, $20 \%$ at Apple, $15 \%$ at Facebook, and $10 \%$ at Twitter. ${ }^{157}$ In 2017 , the number was $20 \%$ at Google and $19 \%$ at Facebook. ${ }^{158}$ Women are even scarcer in leadership roles, comprising only $12.5 \%$ of executives at Silicon Valley companies compared to $18 \%$ in the S\&P $100 .{ }^{159}$

Silicon Valley's technology companies ought to attract a higher-thanaverage share of women; their location in the liberal San Francisco Bay Area

153. See, e.g., Clare McDonald, \#Metoo: Parallels Between the Technology Industry and Hollywood, COMPUTER WKLY. (Oct. 20, 2017, 3:56 PM), https:/www.computerweekly.com/blog /WITsend/metoo-parallels-between-the-technology-industry-and-Hollywood [https:// perma.cc/Q628-TYL8].

154. Mundy, supra note 83 (describing the opposition of several tech companies to a Freedom of Information Act request filed by the San Jose Mercury News for the Department of Labor to release data on the composition of their workforces).

155. Tracy Chou, Where Are the Numbers?, Medium (Oct. 11, 2013), https://medium.com /@triketora/where-are-the-numbers-cb997a57252 [https://perma.cc/8JNM-PGT3].

156. See Hannah Levintova, Meet the Engineer Who Forced Silicon Valley's Gender Problem into the Open, MOTHER JONES (2015), https://www.motherjones.com/politics/2015/o7/siliconvalley-gender-sexism-women-engineers-tracy-chou [https://perma.cc/3C66-SC92].

157. Mundy, supra note 83 .

158. CHANG, supra note 71 , at 7 .

159. Gender Diversity in Silicon Valley: A Comparison of Silicon Valley Public Companies and Large Public Companies (2016 Proxy Season), FENwICK \& West LLP 18 (2017), https://www .fenwick.com/FenwickDocuments/Gender_Diversity_2016.pdf [https://perma.cc/MXS3$\mathrm{K} 6 \mathrm{QX}]$. 
should make them bastions of inclusion and progress. ${ }^{160}$ Instead, Bay Area tech companies do worse than others in an industry that is already sex-segregated: in Silicon Valley, women occupy $20 \%$ of computing jobs, while women hold $25 \%$ of computing jobs in the rest of the country, and nearly $39 \%$ of those in Washington, D.C., the city that tops the list for treating women in tech fairly. ${ }^{161}$ Despite advances in some markets, the technology industry has remained inhospitable to women generally. In fact, women's share of computing jobs has declined dramatically over the past two decades, falling to only $25 \%$ from a high of $36 \%$ in $1991 .{ }^{162}$

Like Hollywood, Silicon Valley relies heavily on top-down, subjective leadership decisions and male social networks that disadvantage women. It begins with the venture capitalists who fund tech start-ups. In 2016, ninety-three percent of the partners at top venture capital funds were men, and ninety-eight percent of the founders they funded were men. ${ }^{163}$ Predicting which tech entrepreneurs will succeed is a subjective and imperfect art; ${ }^{164}$ venture capital firms fall back on familiar stereotypes and insider networks, preferring young, white, male Ivy-League or Stanford dropouts who resemble other tech innovators. ${ }^{165}$ Indeed, many tech companies start off as collaborations among close college friends, who then hire additional friends or acquaintances through close-knit social networks such as fraternities. ${ }^{166}$ Tech entrepreneurs look for a combination of hard skills and subjective qualities, such as innovative thinking and an

160. See David A. Cotter et al., All Women Benefit: The Macro-Level Effect of Occupational Integration on Gender Earnings Equality, 62 AM. SOC. REV. 714, 721, 722, 728-729 (1997) (finding that San Francisco has lowest degree of occupational segregation by sex and lowest sex-based earnings gap of the many metropolitan areas studied).

161. Jeff Clabaugh, DC, Not California, Tops List for Women Working in Tech, WTOP: WASH.'s TOP NEWS (Feb. 22, 2018, 8:33 AM), https://wtop.com/business-finance/2018/o2/dc-topslist-for-women-working-in-tech [https://perma.cc/7BEK-TUKN].

162. CHANG, supra note 71 , at 7 ; see also The Current State of Women in Computer Science, CoMPUTERSCIENCE.ORg [hereinafter Current State of Women], https://www.computerscience.org /resources/women-in-computer-science [https://perma.cc/PZ56-6W7S] (reporting the same statistics).

163. Chang, supra note 71 , at 7 ; Sheelah Kolhatkar, The Tech Industry's Gender Discrimination Problem, NEw YoRKer (Dec. 20, 2017), https://www.newyorker.com/magazine/2017/11/20 /the-tech-industrys-gender-discrimination-problem [https://perma.cc/DT9D-GWP9].

164. PAO, supra note 6o, at 85-86. For supporting evidence, see Tobias Kollmann \& Andreas Kuckertz, Evaluation Uncertainty of Venture Capitalists' Investment Criteria, 63 J. Bus. REs. 741 (2010); Yasemin Y. Kor et al., Resources, Capabilities and Entrepreneurial Perceptions, $44 \mathrm{~J}$. MGMT. STUD. 1187 (2007); Barbara J. Orser \& M.K. Foster, Lending Practices and Canadian Women in Micro-based Businesses, 9 WOMEN MGMT. REV. 11 (1994).

165. CHANG, supra note 71, at 54-55; PAO, supra note 60, at 85-86; Kolhatkar, supra note 163.

166. See supra note $\mathbf{1 3 1 .}$ 
ability to work cooperatively with others in a competitive setting. ${ }^{167}$ It is well known that when managers use their own judgment to hire people based on such subjective factors, they favor those who resemble themselves, ${ }^{168}$ further screening out women and confirming impressions that tech competence is masculine. Relying on tight social networks has a similar exclusionary effect, ${ }^{169}$ even where the underlying groups from which the network is drawn do not explicitly discriminate. Start-ups that hire based on personal connections are less likely to integrate women into core technical roles from the get-go, and this gender inequality gets built into the logic of the firm and persists over time. ${ }^{170}$

Despite widespread use of such insider-favoring processes, there is a prevalent view among tech personnel that the industry is a meritocracy. ${ }^{171}$ Silicon Valley entrepreneurs often share a libertarian philosophy, believing that markets reward talent and effort. ${ }^{172}$ Furthermore, most believe strongly that tech success requires innate genius. ${ }^{173}$ These beliefs, too, can foster and justify stereotyping. Like perceptions that women lack the creativity or commanding presence to be great film directors, cultural images of tech genius almost never have a female face. Research shows that fields such as computer science, mathematics, and philosophy that prioritize inborn brilliance systematically disadvantage women because such brilliance is perceived as a male characteristic. ${ }^{174}$

The business model for startups, which emphasizes starting from scratch and dispensing with rules in pursuit of the bottom line, exacerbates these tendencies by granting managers enormous autonomy and glorifying star performers. ${ }^{175}$ In an industry that features libertarian values, unconstrained authority, and clubbish social networks, it is unsurprising that many who occupy tech's exalted positions develop a strong sense of entitlement to do what they want, including to other people.

167. See Richard Ford, Civil Rights 2.0: Encouraging Innovation to Tackle Silicon Valley's Diversity Deficit, 11 STAN. J.C.R. \& C.L. 155, 161-62.

168. See supra note 131 .

169. See supra notes $132 \& 147$.

17o. Baron, supra note 131.

171. See Ford, supra note 151, at 160, 163-67.

172. Chang, supra note 71 , at $60-63$; Kolhatkar, supra note 163 ; Mundy, supra note 83 .

173. Kolhatkar, supra note 163 ; Mundy, supra note 83 .

174. Sarah-Jane Leslie, et al., Expectations of Brilliance Underlie Gender Distributions Across Academic Disciplines, 347 SCIENCE 262 (2015).

175. Kolhatkar, supra note 163 . 


\section{CHANGE}

The implications for activism and law reform are clear. To end sexual harassment requires large-scale changes, not individualized solutions. ${ }^{176}$ Scholars, lawmakers, advocates, activists, policymakers, managers, employees, and citizens must work together to eliminate sex segregation and abandon unnecessarily subjective selection processes and arbitrary authority in favor of more inclusive, open, and accountable organizations.

Recognizing that structural workplace conditions like sex segregation and unconstrained supervisory authority encourage harassment reveals why some solutions are doomed to fail. It will not work to try to re-educate or sensitize harassers through workplace training or debiasing, for example, as many companies and consultants are doing. ${ }^{177}$ Most harassers already know their behavior bothers their victims or are indifferent to their feelings; they are harassing them in order to reinforce their own status, power, and social identity. Thought control will not work and instead frequently backfires. ${ }^{178}$ Nor will it be enough to punish or shame harassers for abusing their power. It is not simply bad behavior, but the carte-blanche authority that supports and encourages that behavior that must be restrained; in many high-flying positions, mistreating subordinates is so ingrained that it is seen as a central part of the job. Ending harassment is not about retraining or restraining boorish men. Organizational training and in-house complaints have been tried and have largely failed. ${ }^{179}$

176. See Schultz, supra note 2, at 2172-74. The need for systemic changes, as opposed to individual remedies, is a constant theme in employment discrimination law. See generally LaUREN EDELMAN, WORKING LAW: COURTS, CORPORATIONS, AND SYMBOLIC CIVIL RIGHTS 127-33 13738 (2017); Tristin K. Green, Discrimination LaUndeRING: THE Rise of ORGanizational INNOCENCE AND THE CRISIS OF EQUAL OPPORTUNITY LAW (2017).

177. See Mundy, supra note 83 (describing use of implicit bias training in Silicon Valley).

178. See id. (discussing how implicit bias training can backfire); Michelle M. Duguid \& Melissa C. Thomas-Hunt, Condoning Stereotyping? How Awareness of Stereotyping Prevalence Impacts Expression of Stereotypes, 100 J. APPL PSYCHOL. 343 (2015).

179. See Edelman, supra note 176; Frank Dobbin \& Alexandra Kalev, Why Diversity Programs Fail, HARV. Bus. REV. (July-Aug. 2016), https://hbr.org/2016/o7/why-diversity-programs-fail [https://perma.cc/9BYN-R66E]; Feldblum \& Lipnic, supra note 53, at 47-49 (questioning the efficacy of one-size-fits-all training, based on review of social science evidence); see also Susan Bisom-Rapp, An Ounce of Prevention Is a Poor Substitute for a Pound of Cure: Confronting the Developing Jurisprudence of Education and Prevention in Employment Discrimination Law, 22 BERKELEY J. EMP. \& LAB. L. 1 (2001) (reviewing early evidence questioning the value of training programs); Susan Bisom-Rapp, Sex Harassment Training Must Change: The Case for Legal Incentives for Transformative Education and Prevention, 71 STAN. L. REV. ONLINE 62, , 69 (2018) (discussing the EEOC's newfound skepticism of harassment training). 
Without addressing the nature of the hierarchy head-on, we can expect the revolving door of harassers to continue.

Nor will it work to have rules, popularly represented by Vice President Mike Pence's personal rule of never dining alone with women, that limit contact between the sexes. ${ }^{180}$ These rules, like proposals to draw stricter boundaries between work and after-hours activities, ${ }^{181}$ are premised on the old idea that harassment is driven by sexual desire. They rest on the assumption that removing the opportunity for people to have personal contact solves the problem. Yet organizations cannot possibly limit contact between all the people who might conceivably be attracted to each other, at work or after hours. If we should have learned anything by now, it is that we cannot rid the workplace of all sexual attraction, behavior and expression-and indeed, trying to do so is ill-advised. It does not cure sexism and it risks disproportionate harms to sexual and racial minorities, who are often stereotyped and as overly sexual. ${ }^{182} \mathrm{Ad}-$ ditionally, efforts to do so would be futile because the problem driving sexual harassment is not sexual desire; it is entrenched workplace sexism.

More fundamentally, such rules are based on a misguided effort to control individual thought and behavior, rather than reshape the organizational conditions that channel that behavior in harmful ways. True, unwanted sexual advances and other sexual humiliations are often used as a weapon to exclude or humiliate women and others. But so are myriad other nonsexual actions, as described above. These rules encourage even more sex segregation, casting all male-female interactions as inherently sexual and denying women the same informal access to powerful sponsors and social networks afforded to their male peers. Once we understand that sex segregation is a cause of-and not a solution to-sexual harassment, it becomes clear that ending harassment requires tearing down the barriers of sex and gender that prevent people from interacting with each other as workplace and social equals, rather than erecting new ones. The targeted barriers must include those formed by race, sexual orientation, disability, and the like, not simply sex and gender.

180. See Ashley Parker, Karen Pence Is the Vice President's 'Prayer Warrior,' Gut Check and Shield, WASH. POST (Mar. 28, 2017), https://www.washingtonpost.com/politics/karen-pence-isthe-vice-presidents-prayer-warrior-gut-check-and-shield/2017/03/28/3d-a26ce-oao1-11e78884-96e6a6713f4b_story.html [https://perma.cc/GYZ9-UKWT].

181. See, e.g., Josh Barro, More Formal, Less 'Fun' Office Cultures Would Be Good for All of Us, Bus. INSIDER (Oct. 10, 2017, 10:49 PM), https://nordic.businessinsider.com/harvey-weinsteinoffice-cultures-2017-10 [https://perma.cc/E7RY-Y89K]. Such a suggestion seems unrealistic in an age where technology and social media have effaced the boundary between work and other realms.

182. See Schultz, supra note 2 , at $2158-63$. 
First and foremost, then, ending sex-based harassment means ending workplace sex segregation and inequality. I advocated this position years ago, but not enough advocates and policymakers took up the challenge. This time around, antiharassment activists seem to grasp this point and are pressing to integrate male-dominated jobs, occupations, and industries. The \#TimesUp movement's original "Dear Sisters" letter, for example, called for "a significant increase of women in positions of leadership and power across industries" and "equal representation, opportunities, benefits and pay for all women workers, not to mention greater representation of women of color, immigrant women, and lesbian, bisexual, and transgender women" in all industries. ${ }^{183}$ An affiliated group, 505oby2020, seeks to integrate women into all core leadership positions in Hollywood. ${ }^{184}$ Reform groups in Silicon Valley are similarly advocating for gender parity in entrepreneurial and technical roles. ${ }^{185}$ Similar demands are being made for racial and sexual minorities in other unequal industries. ${ }^{186}$

183. Open Letter from Time's Up, N.Y. TIMES (Jan. 1, 2018), https://www.nytimes.com/interactive /2018/o1/o1/arts/o2women-letter.html [https://perma.cc/8LVM-7594].

184. See, e.g., 5050BY2020, https://5050by2020.com [https://perma.cc/5A4R-WMYN] (asking "networks, studios, talent agencies, unions and other organizations" to integrate women, people of color, LGBTQIA, and people with disabilities into core decisionmaking positions by 2020).

185. See, e.g., AnitaB.org Calls for Uber to Publish Plans for Change, ANITAB.org, https://anitab .org/news/abi-in-the-news/uber-plans-for-change [https://perma.cc/H4SX-8FTY]; The Kapor Capital Founder's Commitment, KAPOR CAPITAL, https://www.kaporcapital.com /founders-commitment [https://perma.cc/VFV7-8387]; PROJECT INCLUDE, http://project include.org [https://perma.cc/6NY9-FA2G]; Victoria Turk, What Men in Tech Can Do to Address Terrible Gender Inequality, WIRED (Dec. 3, 2017), http://www.wired.co.uk/article /heforshe-metoo-men-in-tech-need-to-step-up-for-gender-equality [https://perma.cc /GL24-FMPS] (describing a UN initiative advocating for the technology industry to set specific quantifiable goals for equal pay, fair parental leave policies, and gender parity in senior leadership by 2020); see also Ali Breland, Black Lawmakers Give Tech Sector Low Marks Amid Silicon Valley Trip, HuL (Oct. 17, 2017), http://thehill.com/policy/technology/355909-blacklawmakers-are-considering-legislative-vehicle-to-get-tech-to-increase [https://perma.cc/ $\left.\mathrm{C}_{2} \mathrm{P}_{3}-\mathrm{PFH}_{7}\right]$.

186. See, e.g., Gender-related UN Secretariat Policies, UnITED Nations, http://www.un.org /womenwatch/osaginew/fpgenderpolicies.htm [https://perma.cc/8JZQ-7UE7]; Darren Sands, A Top Democratic Group Has Increased Staff Diversity for Key Midterms, BUZZFEED (May 15, 2018, 2:36 PM), https://www.buzzfeed.com/darrensands/dccc-staff-diversity-black -candidates [https://perma.cc/3YF4-9JRA]; BLACK, ASIAN AND MinORITY ETHNIC (BAME) TALENT IN GAMES, http://www.bameingames.org [https://perma.cc/VTY7-TCVH]; CATALYST, http://www.catalyst.org/be-inclusive [https://perma.cc/9HRE-YDBE]; INCLUSV, https://inclusv.com/ [https://perma.cc/SN2C-D4QP]; PARADIGM FOR PARITY, https:// paradigm4parity.com [https://perma.cc/DG2J-XUA3]; PARITY.ORG, https://www.parity .org [https://perma.cc/Q9DH-NH85]. 
Time-honored principles and lessons from employment discrimination law can further the project. Although the business benefits of diversity may induce some companies to act, ${ }^{187}$ historically, few American industries made significant strides toward race or gender integration without major campaigns to enforce Title VII or other laws prohibiting workplace discrimination. ${ }^{188}$ Even today, the fight to end sex segregation, inequality, and harassment must include initiatives by state and federal agencies and private class actions to enforce these laws. ${ }^{189}$ The risk of being blackballed in industries that run on social networks and reputational capital is too high for individuals facing discrimination to bear the burden of bringing lawsuits alone. During the Obama Administration, the federal government began pursuing film studios and tech firms that discriminate in hiring, promotion, and pay. The Department of Labor sued Google, Oracle, and Palantir for sex-based hiring and pay disparities, ${ }^{190}$ and the EEOC began investigating the major Hollywood studios for sex discrimination by failing to hire female directors. ${ }^{191}$ We should insist that these efforts continue.

Lawsuits like these should also challenge sex-based harassment, clarifying its link to vertical and horizontal forms of sex segregation and exposing the full spectrum of sexual and nonsexual harassment and unequal treatment - the "thousand paper cuts" that debilitate so many women and gendernonconforming people. Advocates can also push for innovative remedies to address and prevent the recurrence of harassment, such as numerical goals to ensure that women of all races are fully integrated into prized jobs and leadership

187. See Richard Thompson Ford, Civil Rights 2.o: Encouraging Innovation to Tackle Silicon Valley's Diversity Deficit, 11 STAN. J. C.R. \& C.L. 155, 176-178 (2015) (advocating for allowing Silicon Valley tech companies to innovate as a way to achieve diversity).

188. In the early days of Title VII enforcement, for example, the federal government challenged racial segregation in many leading industries, including steel, trucking, construction, telecommunications, manufacturing, law enforcement, firefighting, and even motion pictures. See, e.g., Int'l Bhd. of Teamsters v. United States, 431 U.S. 324 (1977) (trucking); United States v. Allegheny-Ludlum Indus., 517 F.2d 826, 834 ( 5 th Cir. 1976) (steel). After pressure from the women's rights movement, the federal government also began to challenge sex segregation in industries such as steel, telecommunications, and retail. See Schultz, supra note 8 , at $1031-35$.

189. See Schultz, supra note 99, at 22-25.

190. See Seth Fiegerman, Google Is in Court Fighting over How It Pays Women, CNN TECH (Aug. 9, 2017), http://money.cnn.com/2017/o8/o9/technology/business/google-labor-lawsuit/index .html [https://perma.cc/U64Z-QNE2]; Kolhatkar, supra note 163.

191. See Maria Giese, Weinstein Scandal Should Affect the Outcome of the EEOC Hollywood Probe, HOLLYwOOD REP. (Oct. 12, 2017, 6:31 PM PDT), https://www.hollywoodreporter.com /news/weinstein-scandal-should-affect-outcome-eeoc-hollywood-probe-guest-column-104 8414 [https://perma.cc/Z9V7-K3NQ]. 
positions on equal terms ${ }^{192}$ - not just in token numbers - and that men are similarly integrated into traditionally female jobs. Breaking up these patterns of inequity is crucial to giving marginalized people the presence and power to resist harassment and stereotyping - and, ultimately, to changing the hearts and minds of incumbents who do not yet see them as equals. Campaigns to reach shareholders, advertisers, and customers can press for similar results and remedies. Law's aspirations can be mobilized in many settings, pressing for recognition that harassment is an expression of endemic workplace sexism and not a problem of individual sexual advances. ${ }^{193}$

But integration alone will not end harassment; unless the hierarchy itself is restructured, women will simply join the ranks of the overly powerful and will inevitably succumb to the temptations to abuse others that these positions induce in the people who hold them. Scholars have begun to reinvigorate the case for eliminating unnecessarily subjective and arbitrary authority by bosses in the workplace. ${ }^{194}$ Eliminating unnecessary workplace hierarchy is a massive and difficult undertaking that will require long-term efforts on multiple fronts, including employment and labor law reforms, labor and political activism, and tort and contract liability to reshape and restrain higher-ups' arbitrary and abusive authority. ${ }^{195}$ Many activists are also rightly working on the problem from the bottom up, seeking reforms that will empower employees and reduce their structural vulnerability. ${ }^{196}$ Employment discrimination law also holds important lessons for the effort to reign in subjective authority. From its incep-

192. See Local 28 of the Sheet Metal Workers' Int'l Ass'n v. EEOC, 478 U.S. 421,445 (1986) (plurality opinion) (holding that Title VII "does not prohibit a court from ordering, in appropriate circumstances, affirmative race-conscious relief as a remedy for past discrimination"); see also Johnson v. Transp. Agency, 48o U.S. 616, 619-21 (1987) (holding that employers may use affirmative action to integrate traditionally sex-segregated job categories); United Steelworkers of Am. v. Weber, 443 U.S. 193, 209 (1979) (holding similarly in the context of race).

193. See Green, supra note 94, at 167-69.

194. See ANDERSON, supra note 133; Cynthia Estlund, Rethinking Autocracy at Work, 131 HARV. L. REV. 795 (2018) (reviewing ANDERSON, supra note 133).

195. See Ramit Mizrahi, Sexual Harassment Law After \#MeToo: Looking to California as a Model, 128 YALE L.J.F. 121, 142-52 (2018) (listing possible legislative solutions in the wake of \#MeToo and \#TimesUp).

196. See Vicki Schultz, supra note 99, at Principle 6. For examples of proposed reforms, see Regina Austin, Employer Abuse, Worker Resistance, and Tort of Intentional Infliction of Emotional Distress, 41 STAN. L. REV. 1, 4-5 (1988) (proposing the creation of a tort of supervisory abuse); Hands Off, Pants On, UNITE HERE LOCAL 1, https://www.handsoffpantson.org /protecting-and-respecting-women/ [https://perma.cc/K5LP-N57J]; One Fair Wage, RESTAURANT OPPORTUNITIES CTRS. UNITED, http://rocunited.org/our-work/\#one-fair-wage [https://perma.cc/AZ33-8HJP] (proposing the elimination of the tipped wage in favor of a minimum wage for restaurant workers). 
tion, Title VII jurisprudence condemned unduly subjective supervisory authority and closed social networks as breeding grounds for discrimination and stereotyping. Lawyers at the Department of Justice Civil Rights Division and elsewhere secured interpretations of the law pressuring employers and labor unions to abandon highly subjective selection systems that fostered bias or favored people who knew or resembled incumbents. ${ }^{197}$ They fought for more open processes that advertised jobs equally to all, specified relevant skills in advance, and evaluated candidates on a more objective, uniform, and evenhanded basis. Civil rights lawyers succeeded in many industries, rationalizing the workplace in ways the labor movement had sought for decades. ${ }^{198}$ In the name of eliminating race discrimination, the early Title VII revolution helped reign in purely subjective decisionmaking and reliance on exclusionary social networks in favor of more open, neutral processes that that created greater opportunities not only for racial minorities, but for all aspirants who were not favored insiders. ${ }^{199}$

It is time for a new revolution. These same principles should be adapted to today's economy and brought to bear in industries that have not yet fully implemented them. People seeking careers in Hollywood, Silicon Valley, and many other industries and firms cannot count on having the benefit of open hiring processes, objective credentials, or identifiable career paths - factors that create more rationalized employment and hiring systems. Instead, aspirants must pursue and please powerful sponsors and maintain the right social connections if they hope to break into the business. Hollywood has avoided greater rationalization partly because the film industry runs on discrete projects and short-term contracts; third parties, such as talent agencies, buffer accountabil-

197. See, e.g., United States v. Georgia Power Co., 474 F.2d 906, 925 ( 5 th Cir. 1973) (invalidating as racially discriminatory an employer's use of word-of-mouth recruiting because it would exclude Blacks from the "web of information" regarding job opportunities); Rowe v. Gen. Motors Corp., 457 F.2d 348, 359 (5th Cir. 1972) (invalidating as racially discriminatory promotion and transfer procedures that rely on the subjective evaluation of foremen as a "ready mechanism for discrimination"); Local 53 of Int'l Assoc. of Heat \& Front Insulators v. Vogler, 407 F.2d 1047, 1053-54 (5th Cir. 1969) (invalidating as racially discriminatory a union requirement restricting helpers to sons or close household relatives of a current union member).

198. See Vicki Schultz, Rationalizing the Workplace: Title VII's Lasting Contribution to American Society After Fifty Years (2017) (unpublished manuscript) (on file with author) (documenting early enforcement campaigns and caselaw, and describing changes in employers' practices). See generally FRANK DOBBIN, INVENTING EQUAL OPPORTUNITY (2011) (documenting organizational changes).

199. See Schultz, supra note 198 . 
ity. ${ }^{200}$ Silicon Valley firms have operated in a free-wheeling, informal environment that has evaded transparency, such as reporting basic employment data. ${ }^{201}$

In an economy in which soft skills and social networks have become even more important, it is crucial to demand greater openness, objectivity, and accountability. Advocates and agencies have begun to recognize as much. For example, the ACLU's demand for the EEOC to investigate the film industry not only complains of continuing sex segregation: it targets the role of the studios' and talent agencies' discriminatory use of highly subjective hiring practices. ${ }^{202}$ Feminist advocacy organizations in Silicon Valley recommend measures to rationalize unduly subjective selection processes, including open recruiting, structured interviews, more objective criteria, and more standardized decisionmaking. ${ }^{203}$ Consultants and even a few prominent companies, such as Google, espouse a similar approach. ${ }^{204}$ By now, it is clear that the tech industry can no longer be left to regulate itself. State and federal agencies and public interest advocates should throw their weight behind these efforts and demand measures to discipline subjective decisionmaking and dismantle discrimination, as occurred in other leading sectors long ago. While some degree of subjectivity in hiring and supervision is unavoidable, excessively arbitrary supervisory authority and oligopolistic insider-favoring networks can and should be restrained by law and activism. ${ }^{205}$ These systems foster not only targeted discrimination and harassment, but also generalized cronyism and abuse. Ultimately, it is not only women and racial and sexual minorities, but all employees and aspirants, who stand to benefit from structural reforms.

\section{CONCLUSION}

The \#MeToo movement has renewed women's - and all people's - dreams and demands for equal, inclusive workplaces characterized by relations of re-

\footnotetext{
200. See Bielby \& Bielby, supra note 147 , at $369-70$ (discussing the rise of employment contracts and the role of talent agencies); Allen J. Scott, A New Map of Hollywood: The Production and Distribution of American Motion Pictures, 36 REgIONAL STUD. 957, 958-59 (2002) (describing major studios as systems houses that produce a small number of blockbuster films, while relying on a system of flexible specialization for producing most films through discrete contracts with third parties, including independent studios and talent agencies).

201. See Mundy, supra note 84 ; Kolhatkar, supra note 163.

202. ACLU Letter, supra note 146 , at 2-4, 6 .

203. Hiring, INCLUDE, http://projectinclude.org/hiring [https://perma.cc/C775-ZDJE].

204. Mundy, supra note 83 .

205. See ANDERSON, supra note 133 , at 48-52, 128-30, 135-38.
} 
spect and solidarity, rather than discrimination and abuse. We have been here before. This time, let us not be lulled into focusing on symptoms and individual solutions. We must insist that our institutions take on the crucial tasks of dismantling sex segregation and restructuring unconstrained subjective authority in favor of more equal, open, and accountable institutions. Eliminating segregation is crucial if women and men of all types are to interact and work together as equals. Constraining subjective authority is equally important. Not only can reigning in that authority reduce discrimination and stereotyping, but it can also help eliminate harassment and abuse. When bosses and benefactors no longer have carte blanche authority to make or break people's careers on their own say-so, they will have far less ability to mistreat, harass, and retaliate against the less powerful. In the name of equality, in the name of humanity, it is time to demand: no more kings; no more kingmakers.

Ford Foundation Professor of Law and Social Sciences, Yale Law School. I am grateful to Brian Soucek for recognizing the continued relevance of my earlier work to the current conversation and for proposing the idea for this collection-and for the gift of his scholarship and friendship. The same goes for my friend and colleague Anne Alstott. I am indebted also to my research assistants Chris Talbot, Alyssa Peterson, and Samantha N. Smith, and especially to Will McGrew, as well as to Yale Law Journal editors Emily Barreca, Zoe Jacoby, and Cody Poplin for providing outstanding help with research and editing. I dedicate this Article to my amazing daughter Natalie Schultz-Henry, just as I did the original Yale Law Journal article twenty years ago. She still inspires me to work for a better world.

Preferred Citation: Vicki Schultz, Reconceptualizing Sexual Harassment, Again, 128 YALE L.J.F. 22 (2018), https://www.yalelawjournal.org/forum/reconceptual izing-sexual-harassment-again. 